\title{
Oil Palm Development and Large-Scale Land Acquisitions in Papua New Guinea
}

\author{
Jennifer Gabriel, Paul N. Nelson, Colin Filer \\ and Michael Wood
}

\section{Introduction}

Throughout the developing world, large tracts of land are being acquired from customary owners by corporations for the purpose of commercial agriculture (Deininger and Byerlee 2011; Anseeuw et al. 2012). This 'land grabbing' typically occurs in conditions of poor governance and results in benefits to powerful elites at the expense of local populations (Nolte 2014). It has been argued that the loss of access to land by customary owners in developing countries will be offset by investments that will create new jobs and bring new knowledge and infrastructures that will benefit the local population (Toft 2013). However, this process can also entail serious long-term consequences for these same local people (Sayer et al. 2012; Feintrenie 2014; Rulli and D'Odorico 2014). Large-scale acquisitions have been going on for a long time in many regions of the world, but there has been a marked recent acceleration to supply an increasing global demand for food, fibre and biofuels (von Braun and Meinzen-Dick 2009; Cotula et al. 2011; Rulli et al. 2013). Those who 
advocate for large-scale investments in productive agricultural land point out that measures should be in place to ensure that the benefits are shared equitably with the local populations (Cotula 2013; Toft 2013).

In Papua New Guinea (PNG), the recent large-scale acquisition of more than 5 million hectares of potential agricultural land has been described as the largest land grab in modern history (Global Witness 2014). This has caused great anguish among customary landowners, and was made possible by the abuse of legal loopholes, bureaucratic incompetence, and 'permissive ambiguities' in the leasing process (Numapo 2013: 4). To prevent such abuses in the future, and maximise the benefits of agricultural developments such as oil palm for customary landowners, transparent consultation and agreements between developer companies and representative landowner groups will be needed (Nelson et al. 2014). Our intention in this chapter is to facilitate such change by describing the nature of the actors and their actions to date, with a particular focus on landowner representatives and corporate developers.

We focus on proposed oil palm plantation projects for three reasons. First, oil palm has been the most common crop proposed for largescale agricultural development schemes in PNG, so oil palm schemes account for 2.2 million of the total of more than 5 million hectares of land that has been alienated through the grant of 'special agricultural and business leases' (SABLs). Second, a focus on this particular industry allows us to assess the nature and activities of players more readily than if we examined all the other proposals for crops with less specific requirements for establishment of a viable economic enterprise. Finally, the palm oil industry has been a major transformer of landscapes and livelihoods throughout the tropics in the recent past, and is likely to remain so in the foreseeable future (Sheil et al. 2009; Cramb and Curry 2012; Sayer et al. 2012).

We reveal examples of complex interactions in specific policy and political contexts between people representing the interests of landowners, companies and government agencies, as well as the failure of government officials to ensure compliance, accountability and transparency in all stages of the leasing process. An understanding of these developments gives insights into how they occurred and how future abuses of people's rights might be prevented. We also identify some opportunities for improved outcomes in programs to rationalise the use of land. 


\section{Land Acquisitions for Oil Palm Development}

In PNG, the law does not allow for the permanent alienation of customary land. Around 31 per cent of PNG's current palm oil production originates from fruit produced by smallholders, with the remainder originating from the plantations of the two oil palm companies, New Britain Palm Oil Ltd and Hargy Oil Palms Ltd. The smallholders fall into three categories: those who cultivate oil palm on their own customary land; those in occupation of 6-hectare blocks established on state land under so-called land settlement schemes; and those who have gained access to other people's customary land through clan land usage agreements (Koczberski et al. 2013; also Chapter 5, this volume). Most of the plantations operated by the existing two palm oil-producing companies are on land alienated during the time of the Australian administration, although they also operate some 'mini-estates' on land subleased from groups of customary landowners holding SABLs (see Chapter 6, this volume). The two oil palm companies started making use of these lease arrangements in the late 1990s, but the amount of land they acquired through this process is only a tiny fraction of the area of more than 5 million hectares allocated to other companies under SABLs issued since 2003 (Filer 2011, 2012a; Moore 2011; Winn 2012; Nelson et al. 2014). Most of this land has been subleased to foreign investors, which has caused an outpouring of frustration and anger among rural people in many parts of the country about the loss of rights to their land and resources (Mirou 2013; Mousseau 2013; Numapo 2013).

The SABL process was originally designed to enable customary landowners to use their land productively for business development purposes and thereby gain access to the cash economy (Oliver 2002; Filer 2011). The fundamental title remains with the customary owners, but other rights and components of the title can be partially alienated through the SABL mechanism. Land acquisition through this mechanism involves a threestep process (Table 7.1). First, the state acquires a lease over the customary land, sometimes referred to as the 'head lease', which is executed between the customary landowners and the Minister for Lands and Physical Planning on behalf of the state. Then the state issues an SABL to a family or corporate body approved by the customary landowners. This entity may then grant a sublease to a developer or investor on the basis of this SABL. Due to the compensation provisions in many of the development agreements, it is virtually impossible for most villagers to reclaim the land that has been leased or subleased with their supposed approval. In these 
circumstances, leasing land becomes a form of self-dispossession (Anderson 2010: 13). In some cases, this bureaucratic process of commercialising customary land in effect transfers clan rights to one or more individuals who may not be clan leaders but are supported by a developer who has a close connection with elected politicians or government officials.

While the main justification for the scale of alienation was the establishment of large-scale commercial agricultural ventures, it is now clear that many of the development agreements were being used as a pretext for logging, with many developers having no experience or interest in establishing the agricultural industries promised in the agreements (Nelson et al. 2010, 2014; Filer 2011; Winn 2012).

Table 7.1 Summary of the process intended by government (since approximately 2003) for large-scale agricultural developments in Papua New Guinea, and the variations that have occurred.

\begin{tabular}{|c|c|}
\hline Intended process and actors & Variations that have occurred \\
\hline $\begin{array}{l}\text { Customary landowners and developer } \\
\text { agree on a development proposal for } \\
\text { a particular parcel of land. }\end{array}$ & $\begin{array}{l}\text { Developer and landowner companies } \\
\text { frequently changed in structure and } \\
\text { ownership. }\end{array}$ \\
\hline $\begin{array}{l}\text { Customary landowners of land parcel } \\
\text { form incorporated land group (ILG) } \\
\text { and register it with the state. }\end{array}$ & $\begin{array}{l}\text { Individuals (usually some landowners, not } \\
\text { necessarily living on their customary land) } \\
\text { formed ILG without full consent of landowners. } \\
\text { Multiple dissenting ILGs formed. } \\
\text { ILGs initiated negotiations with alternative } \\
\text { developers and new projects were formulated, } \\
\text { which may or may not involve oil palm. }\end{array}$ \\
\hline $\begin{array}{l}\text { Land parcel surveyed and Local Land } \\
\text { Court approves agreement reached } \\
\text { among landowners. ILG registers } \\
\text { land parcel for development with the } \\
\text { state. Application for lease-leaseback } \\
\text { lodged with Provincial Government } \\
\text { and forwarded to Department of } \\
\text { Lands and Physical Planning (DLPP). } \\
\text { Land investigation report prepared by } \\
\text { Provincial Lands Office and forwarded } \\
\text { to DLPP. }\end{array}$ & $\begin{array}{l}\text { Boundaries were not clearly defined or agreed. } \\
\text { Overlapping boundaries for land parcels } \\
\text { nominated in competing development } \\
\text { proposals. } \\
\text { Land investigations and awareness programs } \\
\text { funded by entities outside the government and } \\
\text { mostly by the developers. } \\
\text { Land investigation report not prepared or not } \\
\text { properly prepared. } \\
\text { Landownership disputes not properly } \\
\text { investigated. } \\
\text { Landowner representatives and ILG } \\
\text { representatives manipulated by developers } \\
\text { to fast-track the issuing of the special } \\
\text { agricultural and business lease (SABL) titles. }\end{array}$ \\
\hline $\begin{array}{l}\text { ILG leases land parcel to the Minister } \\
\text { of Lands on behalf of the state at no } \\
\text { rent ('head lease' or 'customary land } \\
\text { dealing'), which formalises the title } \\
\text { and allows transfer to non-citizens. }\end{array}$ & $\begin{array}{l}\text { Government departments lost records } \\
\text { and acted outside of the law. }\end{array}$ \\
\hline
\end{tabular}




\begin{tabular}{|c|c|}
\hline Intended process and actors & Variations that have occurred \\
\hline $\begin{array}{l}\text { Minister of Lands grants SABL back to } \\
\text { 'a person, group or incorporated body' } \\
\text { (e.g. an ILG) approved by customary } \\
\text { landowners for a period of up to } \\
99 \text { years for the purpose of agricultural } \\
\text { or business development at no rent. }\end{array}$ & $\begin{array}{l}\text { Minister leased land to a company (to whom } \\
\text { customary landowners have not agreed such } \\
\text { a lease should be granted) rather than ILG. } \\
\text { Projects sometimes approved on the basis } \\
\text { of agricultural plans submitted to Department of } \\
\text { Agriculture and Livestock (DAL) by a developer } \\
\text { who is no longer involved in the project. }\end{array}$ \\
\hline $\begin{array}{l}\text { ILG makes sublease (development } \\
\text { agreement) with developer } \\
\text { (a registered company). Foreign } \\
\text { developers should have Investment } \\
\text { Promotion Authority (IPA) certification } \\
\text { to conduct oil palm development. } \\
\text { Sublease should be registered with } \\
\text { DLPP. Full proposal should include } \\
\text { evidence of the technical and financial } \\
\text { capacity of the developer, land use and } \\
\text { capability maps, design and layout of } \\
\text { nurseries, plantations and mills, proof } \\
\text { of landowner consent and minutes of } \\
\text { a public hearing, as well as various } \\
\text { endorsed documents from provincial } \\
\text { and local-level governments supporting } \\
\text { the project proposals. }\end{array}$ & $\begin{array}{l}\text { Brokers negotiated agreements. } \\
\text { Agreements lacked transparency } \\
\text { in negotiations. } \\
\text { SABL grantees often did not return to } \\
\text { the DLPP to register their subleases } \\
\text { as prescribed. } \\
\text { Subleases were transferred between } \\
\text { developers without registration. } \\
\text { Developers not licensed by the IPA to conduct } \\
\text { oil palm development in PNG. } \\
\text { Sublease agreements grossly unfair to the } \\
\text { landowners in terms of ownership of the } \\
\text { infrastructure development and the tree crops. } \\
\text { Foreign developers mostly lacked financial } \\
\text { backing of an overseas parent company with } \\
\text { sufficient experience in oil palm development. }\end{array}$ \\
\hline $\begin{array}{l}\text { DAL assesses feasibility of the } \\
\text { proposal and gives approval. }\end{array}$ & $\begin{array}{l}\text { DAL did not adequately assess proposal } \\
\text { or monitor progress. } \\
\text { Political pressures placed on government } \\
\text { officials by senior ministers and politicians } \\
\text { to fast-track SABL applications. }\end{array}$ \\
\hline $\begin{array}{l}\text { Developer applies to PNG Forest } \\
\text { Authority (PNGFA) for forest clearing } \\
\text { authority (FCA). }\end{array}$ & $\begin{array}{l}\text { Logging proceeded without FCA. } \\
\text { DAL officials supported the view of developers } \\
\text { that logging activities within SABL areas } \\
\text { were justified in order to fund the proposed } \\
\text { agricultural project. }\end{array}$ \\
\hline $\begin{array}{l}\text { Developer proceeds with forest } \\
\text { clearing, establishment and operation } \\
\text { of plantation according to sublease } \\
\text { agreement, monitored by PNGFA, } \\
\text { which ensures that no more than } \\
500 \text { hectares are cleared at one time, } \\
\text { and by DAL, which ensures adherence } \\
\text { to other applicable regulations and } \\
\text { codes of practice. }\end{array}$ & $\begin{array}{l}\text { Developer cleared forest and exported logs } \\
\text { from areas much larger than } 500 \text { hectares. } \\
\text { Developer did not implement agricultural } \\
\text { development plan. }\end{array}$ \\
\hline
\end{tabular}

Sources: Derived from descriptions by Oliver (2002), Moore (2011), Filer (2012b), Mirou (2013) and Numapo (2013).

Note: There are discrepancies between various versions of the process described here, since the sources focus on different aspects and involve interpretation of several sets of rules that were produced at different times for different reasons. 
A commission of inquiry (COI) established by the PNG government in 2011 found much legally questionable activity and serious abuse and subversion of the SABL process (Mirou 2013; Numapo 2013). Commissioner Nicholas Mirou noted 'one unmistakable cry from the vast majority of the rural population of PNG [for] development', along with frustration arising from unmet expectations of benefits from exploitation of their land by developers (Mirou 2013: 167). Two of the three commissioners submitted their reports to the Prime Minister in June 2013, and these were later tabled in Parliament (see Chapter 8, this volume). Along with a number of recommendations to improve transparency, the inquiry recommended that the SABL process be reserved for the development of high-impact projects, with strict conditions to ensure maximum landowner benefit and participation. While in principle these recommendations point to some positive reforms, the government has been slow to remedy situations where evidence of criminality or negligence was uncovered.

\section{Oil Palm Development Proposals}

We examined 29 proposed oil palm projects associated with 51 separate SABLs in 10 different provinces (Table 7.2). The areas shown as being earmarked for the planting of oil palm are those specified in the development plans or environmental impact statements submitted to the PNG government. Where these areas are 'unknown', this is normally due to the fact that no such plans have so far been submitted or sighted.

Most of the development proposals we examined are 'agro-forestry' proposals involving oil palm development. The term 'agro-forestry', which is commonly used in the development discourse in PNG, and that we use in this chapter, has a different meaning in PNG to the more widely accepted definition. In the broader literature, 'agro-forestry' refers to a mixed cropping system that includes trees. In PNG, the term refers to clearance of native forest for timber, followed by agricultural development. 


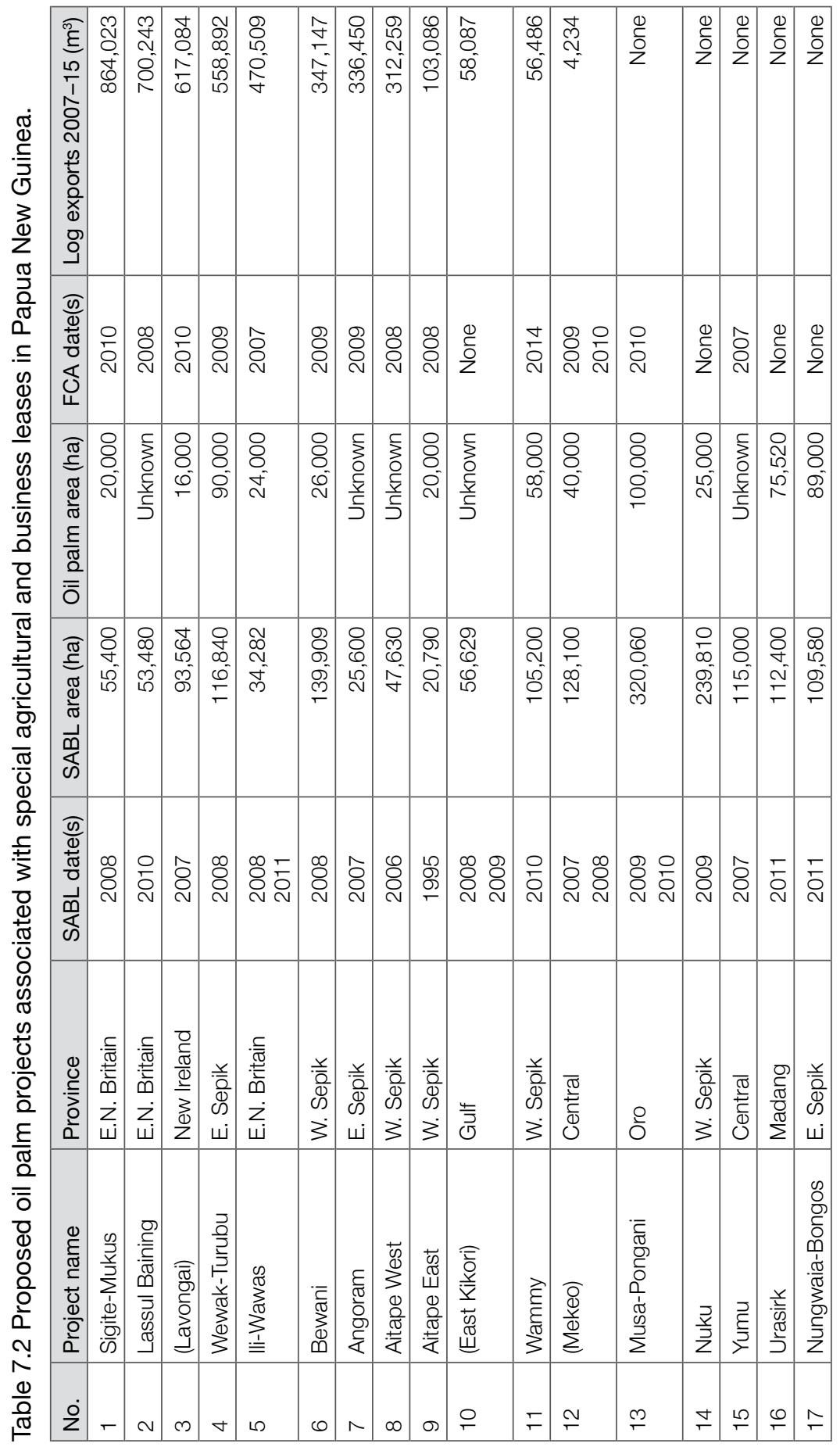




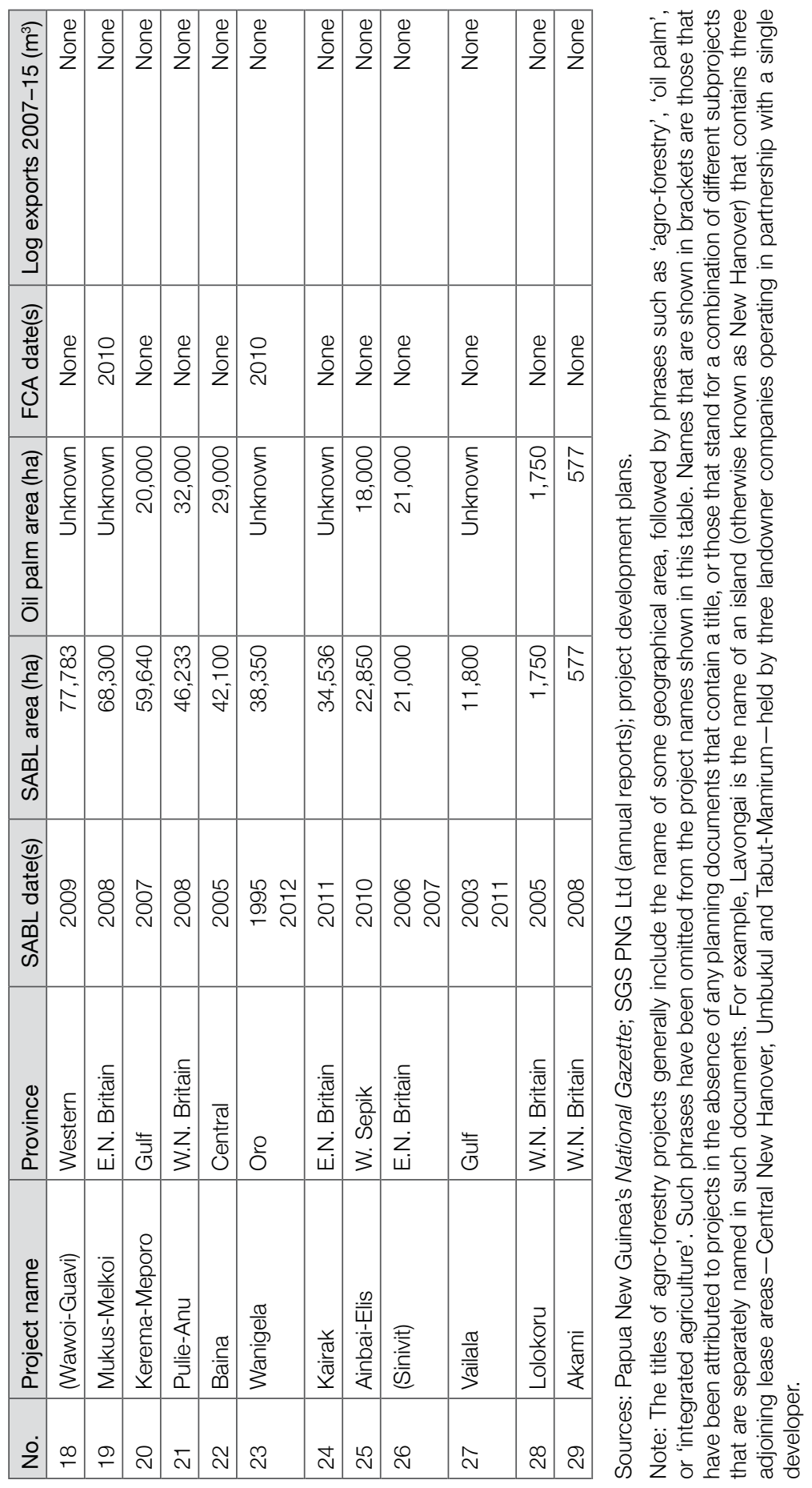


In Table 7.2, the 12 projects that count as operational agro-forestry projects because of their log exports are listed first in order of the total volume of their log exports over the period from 2007 to 2015. All but one of these projects has been exporting logs under the terms of a forest clearing authority (FCA) issued by the PNG Forest Authority (PNGFA), although some of these licences have been suspended or cancelled at one time or another. Most of the remaining 17 projects have never been granted an FCA, and the revenues from log exports have not been used to finance any kind of agricultural development. These projects are therefore listed in order of the size of the SABLs acquired by their proponents. The last two projects in the list are examples of the 'mini-estates' established in the vicinity of the existing oil palm schemes in West New Britain Province (see Chapter 6, this volume), and they do not count as agro-forestry projects since log export revenues have not been treated as the basis for financing their development.

Table 7.3 shows the identity and origin of each of the 'development partners' who have obtained subleases from the landowner companies holding SABLs. It also shows the dates on which the holders of these subleases were registered with the Investment Promotion Authority (IPA), whether they were registered to undertake oil palm production (ROP), and whether there is documented evidence of their capacity to do so (COP), either on their own account or through their parent companies. ${ }^{1}$

In many cases it was difficult to identify the developers due to frequent changes in agreements and lack of the legally required registration of the participants or their agreements. This is partly due to the developers and landowners trying to keep their involvement in SABLs secret. Logging companies have also been known to set up fake incorporated land groups (ILGs) to further confuse the process (Anderson and Lee 2010: 4).

Data was obtained from the COI reports presented to Parliament by Prime Minister Peter O’Neill in September 2013 (Mirou 2013; Numapo 2013), which cover 49 of the 75 leases investigated by the Commission, as well as the transcripts of COI hearings in individual provinces, especially the hearings conducted by Commissioner Jerewai, who failed to finalise his own report (see Chapter 8).

1 In those few cases where the sublease holder is a joint venture between a landowner company and a foreign company, the 'parent company' shown in Table 7.3 is the parent of the foreign company. 
Aside from company records filed with the IPA, and the annual reports on log exports by the 'forest industry participants' recognised by the PNGFA, we also consulted company annual reports, industry and media reports, academic articles, stock market announcements, and stock analyst reviews. Company reports provided information on the scale and investment portfolios of public companies in oil palm development and processing, while analyst reviews provided broader information on market trends and industry responses. Information about the existing oil palm plantations and companies was obtained from the PNG Palm Oil Council.

Table 7.3 Developers of proposed oil palm projects associated with special agricultural and business leases in Papua New Guinea.

\begin{tabular}{|l|l|l|c|c|c|c|}
\hline No. & $\begin{array}{l}\text { Sublease holder(s) } \\
\text { in 2011 }\end{array}$ & $\begin{array}{l}\text { Parent company } \\
\text { in 2011 }\end{array}$ & $\begin{array}{l}\text { Country } \\
\text { of origin }\end{array}$ & $\begin{array}{c}\text { IPA } \\
\text { date(s) }\end{array}$ & ROP & OPC \\
\hline 1 & $\begin{array}{l}\text { Gilford \& Sinar Tiasa } \\
\text { (PNG) }\end{array}$ & Rimbunan Hijau & Malaysia & $\begin{array}{c}2007 \\
2010\end{array}$ & Y & Y \\
\hline 2 & KK Connections & Kerawara & Malaysia & 2010 & $\mathrm{~N}$ & $\mathrm{~N}$ \\
\hline 3 & Tutuman Development & Mantorras PNG & Malaysia & 1999 & $\mathrm{~N}$ & $\mathrm{~N}$ \\
\hline 4 & Sepik Oil Palm Plantation & $\begin{array}{l}\text { Wewak Agricultural } \\
\text { Development }\end{array}$ & Malaysia & 2008 & $\mathrm{Y}$ & n.a. \\
\hline 5 & $\begin{array}{l}\text { Tzen Niugini \& Tzen } \\
\text { Plantation }\end{array}$ & Kenlox Global & Malaysia & 2004 & $\mathrm{~N}$ & $\mathrm{~N}$ \\
\hline 6 & $\begin{array}{l}\text { Bewani Oil Palm } \\
\text { Plantations }\end{array}$ & $\begin{array}{l}\text { PNG Plantations } \\
\text { Development }\end{array}$ & Malaysia & 2010 & $\mathrm{Y}$ & n.a. \\
\hline 7 & Brilliant Investment & (None listed) & Malaysia & 2005 & $\mathrm{~N}$ & $\mathrm{~N}$ \\
\hline 8 & Vanimo Jaya & (None listed) & Malaysia & 1995 & $\mathrm{~N}$ & n.a. \\
\hline 9 & Mekar Harvest (PNG) & Brilliant Investment & Malaysia & 2007 & $\mathrm{~N}$ & $\mathrm{~N}$ \\
\hline 10 & River Estate Plantations & Reko (PNG) & Malaysia & 2007 & $\mathrm{~N}$ & $\mathrm{~N}$ \\
\hline 11 & Global Elite (PNG) & (None listed) & Malaysia & 2010 & $\mathrm{~N}$ & $\mathrm{~N}$ \\
\hline 12 & Albright & $\begin{array}{l}\text { Willsmart } \\
\text { International }\end{array}$ & Malaysia & 2009 & $\mathrm{~N}$ & $\mathrm{Y}$ \\
\hline 13 & Musa Century & Musa Holdings & Malaysia & 2010 & $\mathrm{~N}$ & $\mathrm{~N}$ \\
\hline 14 & $\begin{array}{l}\text { Skywalker Global } \\
\text { Resources (PNG) }\end{array}$ & $\begin{array}{l}\text { Skywalker Global } \\
\text { Resources }\end{array}$ & $\begin{array}{l}\text { Hong } \\
\text { Kong }\end{array}$ & 2009 & $\mathrm{Y}$ & $\mathrm{N}$ \\
\hline 15 & Aramia Plantations & (None listed) & Unknown & None & $\mathrm{N}$ & $\mathrm{N}$ \\
\hline 16 & Continental Venture & $\begin{array}{l}\text { Giant Kingdom } \\
\text { International }\end{array}$ & Malaysia & 2010 & $\mathrm{n} . \mathrm{a}$. & $\mathrm{Y}$ \\
\hline 17 & SPZ Enterprises (PNG) & Geoff Palm & Australia & 2008 & $\mathrm{~N}$ & $\mathrm{Y}$ \\
\hline 18 & Sovereign Hill & Rimbunan Hijau & Malaysia & 1995 & $\mathrm{~N}$ & $\mathrm{Y}$ \\
\hline 19 & Double Dynasty Lumber & Brilliant Investment & Malaysia & 2008 & $\mathrm{~N}$ & $\mathrm{~N}$ \\
\hline
\end{tabular}




\begin{tabular}{|l|l|l|c|c|c|c|}
\hline No. & $\begin{array}{l}\text { Sublease holder(s) } \\
\text { in } 2011\end{array}$ & $\begin{array}{l}\text { Parent company } \\
\text { in } 2011\end{array}$ & $\begin{array}{l}\text { Country } \\
\text { of origin }\end{array}$ & $\begin{array}{c}\text { IPA } \\
\text { date(s) }\end{array}$ & ROP & OPC \\
\hline 20 & $\begin{array}{l}\text { Pacific International } \\
\text { Resources (PNG) }\end{array}$ & $\begin{array}{l}\text { Grand Pacific } \\
\text { Resources }\end{array}$ & Malaysia & 2006 & N & N \\
\hline 21 & Monarch Investments & Rimbunan Hijau & Malaysia & 1996 & N & Y \\
\hline 22 & PMS Timbers & (None listed) & Malaysia & None & N & N \\
\hline 23 & $\begin{array}{l}\text { Ang Agro Forest } \\
\text { Management }\end{array}$ & $\begin{array}{l}\text { Collingwood } \\
\text { Plantations }\end{array}$ & Malaysia & 2007 & N & Y \\
\hline 24 & $\begin{array}{l}\text { East New Britain Palm } \\
\text { Oil (PNG) }\end{array}$ & $\begin{array}{l}\text { Glory Jade } \\
\text { Investments }\end{array}$ & Malaysia & 2011 & Y & Y \\
\hline 25 & Starlink & Brilliant Investment & Malaysia & 2010 & N & N \\
\hline 26 & Feflo Plantation (PNG) & Feflo (PNG) & Malaysia & 2009 & N & N \\
\hline 27 & Sovereign Hill (PNG) & Rimbunan Hijau & Malaysia & 1995 & N & Y \\
\hline 28 & New Britain Palm Oil & Kulim & Malaysia & 1999 & Y & Y \\
\hline 29 & $\begin{array}{l}\text { Greenlands } \\
\text { Development }\end{array}$ & (None listed) & Malaysia & 2011 & n.a. & N \\
\hline
\end{tabular}

Sources: PNG Investment Promotion Authority and PNG Forest Authority.

\section{State Actors and Their Actions}

According to the conventional wisdom, state actors in PNG-whether elected (as politicians) or appointed (as public servants) — should not only represent the interests of the state. They should also favour the interests of customary landowners, who are their own people, against the interests of foreign companies that seek access to customary land. However, the political and bureaucratic process through which SABLs have been granted to private companies, and agro-forestry projects have been granted other permits and licences as a consequence, shows how the capacity of these actors to represent anyone's interest is constrained by their relationship with other actors whose own interests have often been compromised, or whose involvement in the process may have no legal basis.

In order to obtain an FCA under Section 90B of the Forestry Act, the proponents of an agro-forestry project normally had to begin by assembling a set of ILGs whose representatives could alienate a large area of customary land to the state (see Table 7.1). Local politicians and landowner company directors both played important roles in facilitating the process through which a set of land group certificates was presented to the Lands Department in support of an application for 'their' land to be leased back to a company of 'their' choice. By the time this happened, 
a 'development partner' would normally be party to the process, and may well have helped in its facilitation. In theory, officers of the Lands Department should undertake a 'land investigation' in order to establish the connection between the land group certificates and the customary land under consideration before granting an SABL (Moore 2011). This type of investigation was also meant to establish the free, prior and informed consent of the customary owners to the project for which the land was to be alienated, and that is why the COI went to such great lengths to show that national and provincial lands officers had failed to perform this task in accordance with existing laws and policies.

Once an SABL had been gazetted, if not before, the developer would submit its project proposal to the Department of Agriculture and Livestock (DAL). In order to comply with Section 90B of the Forestry Act, officers of this department were supposed to conduct some form of 'awareness' activity with landowners and other stakeholders to establish the extent of local support for the project. There is some evidence of this activity being undertaken, but the outcomes were not clearly documented. These were likely to be occasions on which the local member of parliament delivered a speech of encouragement to his band of loyal supporters, including landowner company directors, preferably in the company of other political and bureaucratic heavyweights from the national and provincial centres of political power.

Once the DAL staff had placed their stamp of approval on a project proposal, the proponents would attach this to their application for an FCA, which would be sent to the PNGFA. ${ }^{2}$ Knowing that the National Forest Board would not normally approve a large-scale conversion concession in the absence of an environment permit issued by the Minister for Environment and Conservation, the proponents would also have initiated a process of environmental impact assessment once the project proposal had been finalised. The National Forest Board also required a recommendation from the relevant Provincial Forest Management Committee before granting an FCA. Landowner interests should have been represented in the deliberations of that committee, but were normally represented by supporters of the project under consideration. Figure 7.1 shows that the

2 The PNGFA has three component parts: the National Forest Board, which makes key decisions at the national level; a number of Provincial Forest Management Committees, which make recommendations to the Board about activities to be undertaken in their respective provinces; and the National Forest Service, which implements the decisions made by the Board. 
volume of logs exported under FCAs continued to increase, even after the establishment of the COI, and the imposition of a moratorium on the grant of new FCAs, in 2011.

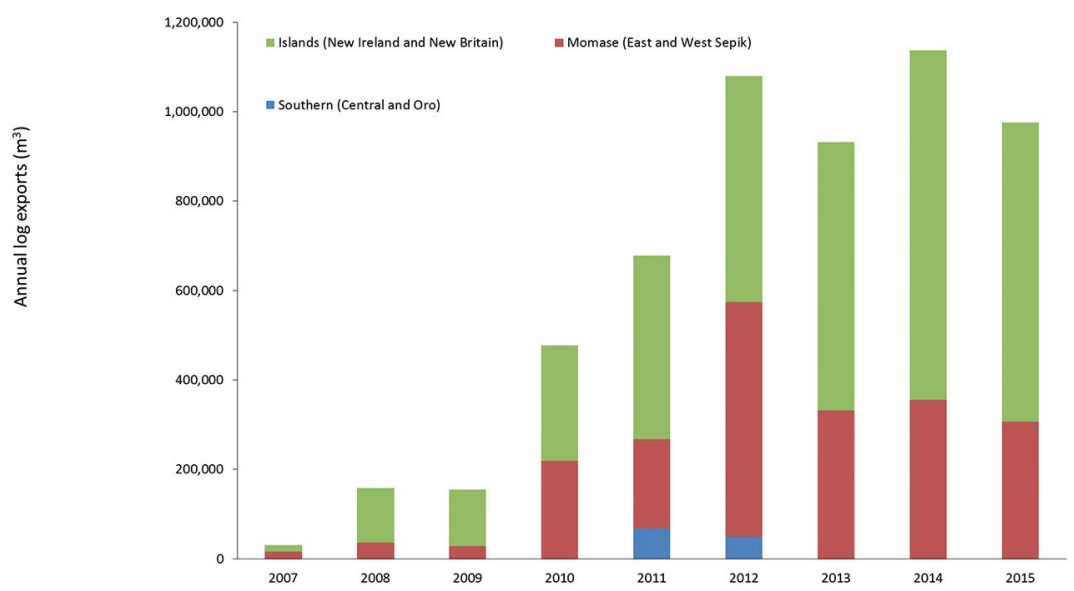

Figure 7.1 Volume of raw log exports from areas covered by FCAs granted to developers of agro-forestry projects, 2007-2015.

Source: SGS PNG Ltd 2008-2015.

In recent years, there has been widespread enthusiasm for agro-forestry projects at all levels of government. This enthusiasm was reflected in the National Agriculture Development Plan (GoPNG 2007), for which DAL is meant to be the implementing agency. Yet DAL staff were also charged with the task of screening and evaluating project proposals to ensure that the proponents had the necessary technical and financial capacities, had conducted the necessary land use assessments, and had produced realistic implementation schedules. However, the COI found 'disturbing evidence' of senior DAL officials simply accepting the idea that logging activities in SABL areas were an acceptable way of financing agro-forestry projects (Mirou 2013: 139; also Chapter 8, this volume).

The perfunctory nature of the project appraisal carried out by DAL staff can also be explained by the institutional disconnection between the national department and its provincial counterparts (Allen 2009). This means that national-level officials had no way to assess the extent of landowner support for a project when it was first presented for appraisal. As Secretary Anton Benjamin explained to the COI: 
There are proposals or projects that have come directly to the Department but where the investors have consulted the landowners-and we are not aware of the manner in which this was done-and so they come with landowners to us to assist them. And there are cases where landowners have their differences. There are people in the community or in the village who are not party to that, who have not been consulted and this is where the problem is. After the endorsement is being given by the Department, we get letters from the landowners to us advising us that they have not been consulted, they are not party to this one and they want the project stopped until it is [sic] all been reviewed. So these are some of the issues that arises from the projects that when investors are actually dealing with the landowners themselves without coming to the Department and so those are issues that we are not aware of until after we have given approval, then we start to see this problem arises (Numapo et al. 2011:24).

Similar sentiments were voiced by other public servants who testified to the COI. They felt they did not have the knowledge or the authority to question the agreements made between landowner representatives and their 'development partners'. And they were even less likely to do so when the 'landowner representatives' included government ministers or other national politicians. For example, the former head of the Lands Department, Pepi Kimas, testified that he was subjected to a lot of 'political pressure ... from the Prime Minister's level down', to grant an SABL for the Bewani oil palm project in West Sepik Province, while the former Provincial Administrator, Joseph Sungi, said that he was 'forced' by officers of the same department to accept a land investigation report that he had not actually sighted (Numapo 2013: 131, 137-8). ${ }^{3}$ This does not mean that all elected politicians have been equally enthusiastic in their support of this particular type of development (see Chapter 6, this volume). However, the nature of PNG's current political system does not provide much opportunity or incentive for members of parliament, including government ministers, to obstruct each other's plans for their respective constituencies, especially when these plans are backed by foreign investors. Public servants have therefore been inclined to act on their perception of the weight of political support behind each project, without considering the possibility of political opposition.

3 In 2012, Mr Sungi was elected to represent an electorate in which nearly all the land was already covered by SABLs that he had authorised in his former capacity as Provincial Administrator. 


\section{Developers and Their Actions}

The investors in agro-forestry projects, who have normally been the holders of subleases issued by the holders of SABLs, can be classified by reference to the identity of their owners or shareholders, the assets or experience at their command, the types of licence they have obtained from the PNG government, their relationships to other corporate entities, and various other criteria. In some projects, the leasing arrangements have involved a joint venture between a landowner company and a foreign company, but the majority of projects have involved a sublease by a landowner company to a foreign investor. Some project proponents already have had a track record in the PNG forestry sector, while others have been new to the country, but established companies and new entrants have both been making use of the SABL mechanism to gain access to timber (Filer 2013). In addition to providing access to new sources of timber for export, one of the reasons that SABLs have been attractive to foreign investors is that the value of land and timber assets can be traded on a foreign stock exchange. On the Kuala Lumpur Stock Exchange, for example, land can be traded in similar ways to stocks and bonds.

Our analysis of oil palm SABLs has revealed that around half of the projects involved negotiations with alternative developers before or after the COI hearings, while some have engaged multiple developers. This has been problematic when the project has been approved on the basis of agricultural plans submitted to DAL by a developer that is no longer involved in the project. Part of the problem of regulation, as the COI was told by the Registrar of Titles, is that the SABL grantees rarely returned to the Lands Department to register their subleases, so the Department and the Registrar were often not aware of the transactions that had transpired after the state lease had been granted.

Twenty-six of the 29 oil palm project proposals we investigated involved investors from Malaysia (Table 7.3). The most prominent among these has been the Rimbunan Hijau (RH) group, a large and diverse multinational company, with many business activities in PNG, including logging, in which it is the country's dominant player. $\mathrm{RH}$ is involved in logging and oil palm plantations in Malaysia through three public companiesJaya Tiasa, Subur Tiasa and Rimbunan Sawit. It has approximately 176,000 hectares of land already planted to oil palm in Sarawak. 
Nine of the investors had individual shareholders, with no identified corporate entity in the shareholding structure. This form of ownership may be something of an illusion if it constitutes a way of limiting or concealing corporate liability. Where the activities of a corporate group are highly integrated and interconnected, to the extent that each unit can be seen as performing a function conducive to realising the group's common economic goal, regulators can disregard the formal separation between the units and impose liability on the parent, regardless of which members of the group were actually responsible for a particular action (Amnesty International 2014).

Most of the developers could produce no evidence of being licensed to invest in oil palm projects by the IPA, which also functions as a regulator. Only 10 of them could be clearly identified as having the financial backing of an overseas parent company with demonstrable experience in oil palm development, and four of these were $\mathrm{RH}$ subsidiaries. One proposal (the Lolokuru estate in West New Britain) was an initiative of New Britain Palm Oil Ltd (NBPOL), the largest palm oil company already operating in PNG, which has recently become a wholly owned subsidiary of the Malaysian multinational Sime Darby. Another of the smaller projects (the Akami estate in West New Britain) would also be dependent on NBPOL as its sole customer. Aside from $\mathrm{RH}$, there were four other foreign investors with some experience of oil palm development, all of them owned by Malaysian shareholders. Some of the investors (including $\mathrm{RH}$ ) have established markets for non-certified palm oil, and are not members of the Roundtable on Sustainable Palm Oil (RSPO), while others have stated an intention to seek certification. Investors differ in the extent of support they have received from government; $\mathrm{RH}$ is known to have the most government support because of the scale and diversity of its past investments in PNG.

The COI highlighted that the legal status of the SABLs is both complex and questionable. Transparent negotiations in the sublease agreements of some of the SABLs were hindered to a significant extent by landowner company directors and foreign investors undertaking negotiations in the nation's capital, Port Moresby. The COI noted with interest, for example, that before an SABL was granted directly to a foreign investor, Brilliant Investment Ltd, this company entered into an agreement with a local landowner company, Marienberg Hills Development Ltd, which invited the former to undertake logging operations within a former logging concession in the Marienberg area. The landowner company representative signed the agreement with the managing director of Brilliant Investment 
in Port Moresby, yet the transaction was not agreed to by the majority of the landowners, as represented by the shareholders and directors of the company, in contravention of the requirements of the Companies Act (Mirou 2013: 719). Clan signatures collected by government officials, who sometimes never went into the villages to collect the signatures, were often found to be fraudulent and not those of the legitimate clan leaders. This in turn has legitimised the destruction of existing cash crops, such as cocoa and copra, which some villages had spent decades cultivating. These crops have simply been bulldozed to make way for roads and oil palms without the owners being compensated for their losses (Lattas 2014).

Developer actions are driven by global economic factors, corporate and shareholder goals, and the local socio-legal environment. The primary economic factors include strong demand for timber and palm oil, the costs and returns of clearing the forest, establishing and operating plantations and a palm oil mill, and the cost of raising capital. All companies operating in PNG are required by law to register their proposed business activities. In the case of foreign companies entering the country with the express intention to develop large-scale agro-forestry projects, either on their own or in partnership with landowner companies, the IPA's role does not seem to extend beyond the grant of a foreign enterprise certificate (Mirou 2013: 154). It is not given any powers under legislation to specifically require evidence of capital and expertise in the particular type of business activity to be undertaken in a particular area. This has resulted in concessions over many SABLs being given to logging companies with absolutely no agricultural background in their past operations and with a total absence of agricultural specialists among their employees (Mirou 2013: 202-3). In several projects, the terms and conditions in sublease agreements had the effect of putting the SABL title in the control of the developer. In cases such as the Wewak Turubu Integrated Agriculture Project, the sublease holder was a joint venture between a landowner company and a foreign company. Such entities have frequently changed in structure and ownership, and some have acted in the developer's interests rather than that of the landowners.

The COI found that 58 out of 75 SABLs investigated were subleased to developers for 99 years and left no residual rights to the landowners (Numapo 2013: 241). Many of the sublease agreements contain provisions that the COI found to be grossly unfair to the landowners in terms of the ownership of any infrastructure development or tree crops. In the event of objections and disputes arising, legal clauses have been included in 
a number of sublease agreements that allow the developer to take out restraining orders in the National Court and be compensated for loss of revenue and other costs incurred (Winn 2012: 32; Mirou 2013: 693). In these instances, if the lease is terminated by the landlord (normally a landowner company), then compensation for the tenant's (developer's) loss will be borne by the landlord, including the tenant's projected profit from the harvest of oil palm for the duration of the agreement (Mirou 2013: 781).

Many of the land investigations and awareness programs necessary for securing SABLs were funded by entities outside the government, mostly by the developers (Mirou 2013: 158). The lack of government funding placed government officials in vulnerable positions to the extent that they were easily compromised when developers offered to pay for the cost of carrying out land investigation and awareness programs. The COI found that, in most instances, the reports and recommendations made by the government officials were in favour of the developers, with no proper consent obtained from the landowners, involved erroneous land boundary descriptions, and generally entailed unethical manipulation of both landowners and government officials by the developers (Mirou 2013: 181-2). The COI found instances of landowner company and land group representatives being manipulated by developers to fast-track the issuing of the SABL titles, as in the case of the Musa-Pongani project in Oro Province (Numapo 2013: 239).

\section{Landowners and Developers}

In PNG, the 'incorporation' of a customary landowner group means that it is formally recognised as a legal entity, becomes the representative of the customary owners in the formal legal system, and is thus able to enter into agreements and make decisions on behalf of the customary group (Power 2008). However, the complexities of customary land tenure often result in disputes. In new conjunctions of the legal and the social, disputing landowners and marginalised groups have made increasing use of social media, the internet and the mainstream media to pursue their different trajectories of struggle and engagement.

The most frequently expressed motivator for development among PNG landowners is the desire for income, infrastructure and services that may come with agricultural developments. Large-scale oil palm schemes 
can provide income streams that are sustained over fairly long periods of time, unlike short-term alternatives such as logging (Oliver 2002). Other drivers of landowner actions include existing infrastructure, public services, land use, land availability and competing claims to ownership of land. Processes that lead to loss of control over a resource are complex and multidimensional, but commonly involve power imbalance and complex politics organised around the opposition between development and conservation priorities (Nayak et al. 2014). In the determination of land use options, landowners or their representatives have acted to enter agreements with developers, change developers, form alliances, petition the RSPO, attend RSPO meetings, publicly express disapproval, lodge written complaints to government agencies, and participate in national and international forums.

In SABL areas, where the politics of landownership has generated new forms of inclusion and exclusion, some landowner representatives have been making formal alliances with international and national nongovernmental organisations (NGOs) in order to raise awareness of social justice issues involving the development of customary land. These alliances attempt to redress the unequal balance of resources between landowners and developers when it comes to creating, negotiating and contesting leases. Correspondingly, other landowners who prefer the development option draw on support from developers to challenge NGO-landowner alliances. Two case studies, one in Oro Province and the other in East New Britain Province, are presented here to highlight these contrasting strategies.

\section{ljivitari District, Oro Province}

In Chapter 6, Colin Filer has shown how the so-called 'Collingwood Bay scam' featured in the political process that led to the establishment of the COI, and then gained a new lease of life in 2012, after the COI had completed its hearings, when the Lands Department attempted to reissue a pair of SABLs that had been revoked by the National Court 10 years earlier. Since these two SABLs were not thought to be extant when the COI was established, they were not included in the list of 75 leases that were subject to the inquiry. However, the apparent breach of the moratorium imposed on the grant of 'new' leases resulted in a new round of litigation that had the backing of the newly elected Governor of Oro Province, Gary Juffa. 
KASTOM, PROPERTY AND IDEOLOGY

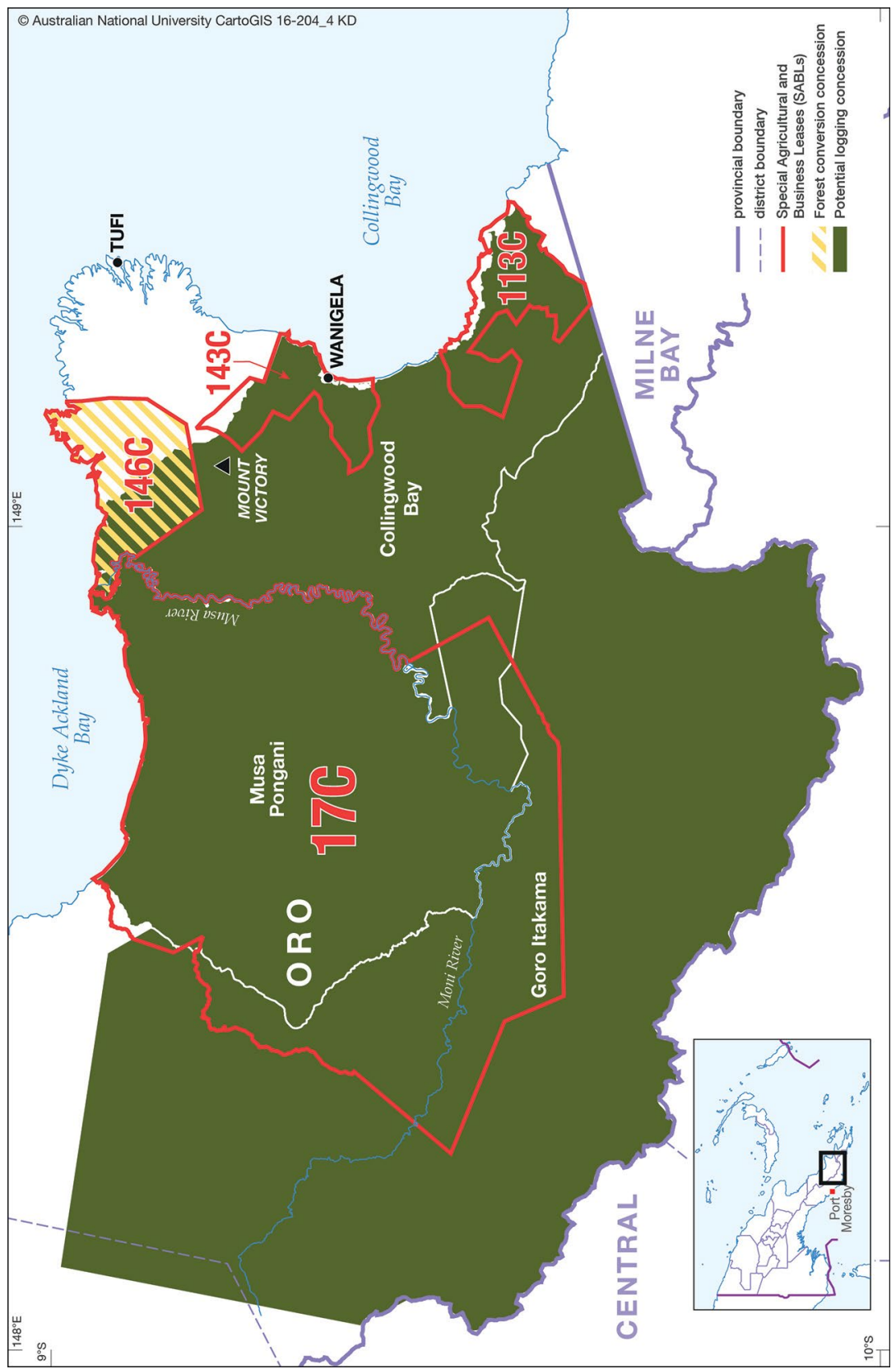

Figure 7.2 Location of SABLs and potential logging concessions in ljivitari District, Oro Province.

Source: CartoGIS, The Australian National University. 
The first of the two leases gazetted in July 2012 covered an area of 21,520 hectares (Portion 113C), and was issued to a landowner company called Sibo Management Ltd for a period of 50 years. The second lease covered an area of 16,830 hectares (Portion 143C), and was issued to another landowner company called Wanigela Agro Industrial Ltd for the same period. Both leases were associated with an oil palm project generally known as the 'Wanigela Integrated Agriculture Project' (which we shall refer to simply as the Wanigela project). These two blocks of land are part of a much larger area of forest in Ijivitari District that has long been regarded by the PNGFA as a cluster of three potential logging concessions known as Collingwood Bay, Musa Pongani and Goro Itakama (Figure 7.2). Two of the SABLs that were investigated by the COI (over Portions 17C and 146C) are also located within this larger area of forest. One of these (Portion 17C) was associated with the 'MusaPongani Integrated Agro-Forest Project' (which we shall refer to simply as the Musa-Pongani project), while the other one (Portion 146) was associated with the 'Tufi-Wanigela Tree Farming Project'. The second of these projects did not involve any proposal to develop an oil palm estate, so is not included in our list of proposed oil palm projects (Table 7.2).

The Musa-Pongani project has been just as contentious as the Wanigela project, but has not attracted the same amount of national and international publicity. It also covered a much larger area of customary land. In January 2009, an SABL over 211,600 hectares of land was issued to a landowner company called Musida Holdings Ltd (MHL) for a period of 99 years. This followed the production of an environmental impact statement by a Malaysian company called Musa Century Ltd (MCL), which envisaged the cultivation of 100,000 hectares of oil palm and 100,000 hectares of other crops (MCL 2008). However, this document shows that Musa Century Ltd had formed a partnership (in 2007) with another landowner company called Musa Valley Management Company Ltd (MVML). When the SABL was issued to MHL, MCL and MVML took legal action to have the lease revoked on the grounds that the landowners had not consented to it, and they obtained a national court order in their favour in January $2010 .{ }^{4}$ Some observers welcomed this decision in the belief that the land would then revert to customary ownership (Pok 2010), as had been the case when the National Court revoked the SABLs over Portions $113 \mathrm{C}$ and $143 \mathrm{C}$ in 2002. But in

$4 \quad$ Musa Valley Management Company Ltd v Kimas [2010] PGNC 281. 
this case, the Lands Department proceeded to grant a new SABL over a considerably larger area (320,060 hectares) to MVML in September $2010 .{ }^{5}$ Meanwhile, in January 2010, a few days after the National Court had made its ruling, the National Forest Board granted an FCA over an even larger area (350,000 hectares) to MVML's 'development partner', MCL, but this licence was later cancelled in August 2011, and no logging has so far taken place.

When the COI came to unravel this case, it was found that the 'successful' landowner company, MVML, had been set up by landowners living in the national capital, Port Moresby, while the other one, MHL, had been set up by landowners living in local villages (Numapo 2013: 208). It was also noted that MVML's apparent success had been diluted by a second court order that granted MHL a right of judicial review, and that seems to explain why the FCA had been cancelled. John Numapo certainly found no evidence to indicate that local landowners had given any more consent to the second lease than they had given to the first one (ibid.: 218-9). From the transcripts of his hearings, it is also evident that MHL had its own 'development partner' (a company called Idamin), that the contest between the two landowner companies had been going on for almost 10 years, and that various politicians and public servants had taken different sides at different points in time. Nevertheless, one witness observed that the directors of the two companies were 'all relatives, very close brothers, uncles, sons, very close', while their former member of parliament compared their relationship to that of 'the Talibans and the headhunters fighting amongst themselves' (Numapo 2012: 88, 95).

A division between the urban and rural branches of a single 'landowning community' may also be part of the history of the Wanigela project, but if so, it has taken a different form because some members of this community have been resolute in their opposition to any form of agro-forestry, and not simply divided in their allegiance to different 'development partners'.

After the Lands Department had granted the SABLs over Portions 113C and $143 \mathrm{C}$ in July 2012, a landowner representative claimed that the original leases over these two portions had been granted in January 1998 (Pok 2012). However, the National Gazette contains no record of the leases being granted around that time, and other sources suggest that they

5 This is the area shown as Portion 17C in Figure 7.2: it includes nearly all of the Musa Pongani forest area and part of the Goro Itakama forest area as well. 
may have been granted in 1995, before the Land Act was amended in such a way as to require their gazettal (Barker 2009). The earlier date would certainly seem to be consistent with the fact that the former premier of Oro Province was already supporting a Filipino company's proposal for an agro-forestry project in Collingwood Bay in 1996, and this proposal had already met with opposition from local and international supporters of a forest conservation project in the same area (Filer 1998: 195, 255). Since then, Collingwood Bay has almost attained the status of a 'sacred site' for members of PNG's conservation policy community (Barker 2004), especially members of the 'antidependency group' (see Chapter 6, this volume). In Oro Province, this group is primarily represented by the Oro Community Environmental Action Network (OCEAN), and the Collingwood Bay Conservation and Development Authority (CBCDA), but also has strong ties to the Centre for Environmental Law and Community Rights.

Towards the end of 2009, local members of this section of the land grab policy network got wind of the landing of a barge full of logging equipment on the shoreline of Portion 113, and its transportation inland to the adjacent Portion 5. ${ }^{6}$ Shortly afterwards, Adelbert Gangai from OCEAN held a 'community consensus meeting' that identified Tony Wong and Vincent Lee as the individuals responsible for this incursion (Gangai 2010). This was a source of some confusion, since these two men were operating out of Tufi, and the companies they represented (Victory Plantation Ltd and Matuf Ltd) were mainly interested in logging the leases associated with the Tufi-Wanigela Tree Farming Project. It was a third company, Ang Agro Forest Management Ltd (AAFML) that was seeking to obtain an FCA over Portions 113C and 143C, and opponents of this Wanigela project thought that Tony Wong and had acquired an interest in it through his relationship with the directors of Keroro Development Corporation Ltd (KDCL), the landowner company to whom the original SABLs had been granted in 1998 or 1995 (Gangai 2010; Nilles 2010). They also believed that Tony Wong was operating as a 'front man' for Rimbunan Hijau (Nilles 2010), as was Eii Sing Hii, who held all the shares in AAFML (OCEAN and CBCDA 2013). ${ }^{7}$

6 Portion 5 covers an area of just under 6,000 hectares that was alienated during the colonial period, and was at that time still owned by the government.

7 In 2010, the company records showed that AAFML had been incorporated in 2006, and that Eii Sing Hii held the shares in trust for unspecified financial interests. 
In November 2009, the Oro Provincial Forest Management Committee approved the grant of an FCA to AAFML, and this is presumably what triggered the appearance of the logging equipment. The National Forest Board accepted the provincial recommendation in January 2010, but its decision was based on incorrect advice to the effect that KDCL still held the land titles. During the course of that year, the loggers and conservationists took turns at engaging different state actors (including members of the police force) in support of their endeavours (Nilles 2010; Pangkatana 2010). As a result of the attendant publicity, the managing director of the PNGFA announced that no logging operation would be approved until the land tenure issue had been resolved (Anon. 2010). The FCA was formally cancelled by the National Forest Board in August 2011, on the same day that it cancelled the FCA granted to the MusaPongani project. In the meantime, in April 2011, AAFML had secured an agricultural lease over Portion 5, but the value of this acquisition was now in doubt.

Gary Juffa was one of the state actors who had supported the conservationists in his capacity as the head of PNG's Internal Revenue Commission. The legal action he supported in his new capacity as Governor of Oro Province was initiated by Lester Seri and six other landowners in November 2012. The defendants in the case were officials of the Lands Department, AAFML and the two landowner companies to whom the SABLs had been granted in July that year. Shortly before the case was launched, one of PNG's national newspapers announced that AAFML's Malaysian parent company, Collingwood Plantations, had been taken over by a much bigger Malaysian company, Kuala Lumpur Kepong Bhd (KLK). ${ }^{8}$ A spokesman for KLK was quoted as saying that the takeover 'presents an opportunity for KLK to develop new oil palm plantations in PNG in view of the increasing difficulty and expense to source suitable land in Malaysia and/or Indonesia'. The newspaper story concluded with the statement that AAFML:

has a 99-year lease on more than 5,992ha in the town [sic] in Northern [Oro], expiring in April 2110; a 49-year sublease on more than [21,520ha] of land in Northern, expiring in August 2061 and a 49-year sublease on more than 16,830ha of land in Northern, expiring in August 2061 (Anon. 2012a).

8 The same article had been published in an English-language Malaysian newspaper on the previous day. 
KLK is a public company listed on the Malaysian stock exchange, and had a market capitalisation of approximately RM24 billion in 2013. The company's annual report for 2013 showed that it had paid almost RM11 million for its controlling interest in the Collingwood Bay leases (KLK 2013a: 123). By the time the acquisition was completed in December 2012, the company's managers might have begun to wonder whether they had got value for their money, since they would now have been aware of the court case in which their new subsidiary was one of the defendants. This problem was compounded by the fact that KLK, unlike most of the developers of agro-forestry projects in PNG, is a member of the RSPO, and was therefore obliged to show that it had obtained the free, prior and informed consent of the local landowners to its development proposal.

This created an opportunity for the dissident landowners to lodge a complaint with the RSPO Secretariat in April 2013, in which they stated that 'the Traditional paramount chiefs of the 9 tribes of Collingwood Bay representing 326 clans have irrevocably stated their disapproval ... in the strongest possible terms of any plans to introduce the oil palm industry in the Collingwood Bay area', and that KLK personnel had recently sought to overcome this opposition by persuading local villagers to sign a new agreement in exchange for ' 100 kina, some rice and canned fish' (OCEAN and CBCDA 2013). The dissidents were then able to secure the backing of the Rainforest Action Network (RAN), an NGO with a particular interest in demonstrating the absence of corporate compliance with RSPO standards. With their support, Lester Seri and Adelbert Gangai attended the RSPO's annual meeting in Sumatra in November that year to reiterate their complaint, while Laurel Sutherlin from RAN observed that KLK's project proposal was 'the ugly face of Conflict Palm Oil and ... would create an entirely predictable and preventable disaster for the people and wildlife of Papua New Guinea' (Sutherlin 2013).

When the RSPO's Complaints Panel found that there was merit in the complaint, KLK responded with a claim that they had obtained the written consent of all local clan leaders to their project proposal, and this evidence was being presented in the court case over the SABLs. They also denied any link to Tony Wong and Vincent Lee (KLK 2013b). Shortly afterwards, in January 2014, the directors of Sibo Management Ltd, the landowner company that had been granted the new SABL over Portion 113C, published an advertorial claiming that all the genuine landowners were fully in support of the Wanigela project, and those opposing it, such as Lester Seri and Adelbert Gangai, as well as Governor 
Gary Juffa, should keep their mouths shut unless they could provide genuine development alternatives (SML 2014). However, this had no material effect on the progress and outcome of the court case.

After the National Court had once again revoked the two SABLs in May 2014, Lester Seri was quoted as saying that:

The people of Collingwood Bay have spoken clearly through the voices of our chiefs that we are against large scale palm oil development on our lands.... The chiefs of our nine tribes have spoken. Tens of thousands of our international allies have spoken. The Roundtable on Sustainable Palm Oil (RSPO) has spoken. And now the National Court of PNG has agreed: these permits are illegitimate. KLK must leave Collingwood Bay immediately and not return (RAN 2014).

KLK did not leave immediately, since the court decision did not affect its right to occupy the lease over Portion 5, where its base camp was located. However, the cancellation of the other leases effectively meant that the Wanigela project would not be viable unless some other way could be found to access the adjoining areas of customary land in the face of opposition from a well organised group of opponents operating at local, national and global scales. ${ }^{9}$ In March 2016, the company announced that it had no personnel in the area, and would remove the equipment still stored on Portion 5 by the end of the year if the 'citizens of the various tribes' with an interest in Portions $113 \mathrm{C}$ and $143 \mathrm{C}$ did not give free, prior and informed consent to the development of the project (KLK 2016).

\section{Pomio District, East New Britain Province}

So long as Gary Juffa remains as Governor of Oro Province, it could be argued that his province and East New Britain Province are at opposite ends of the spectrum of political and public opinion that surrounds the costs and benefits of agro-forestry projects in PNG. With very few exceptions, all of East New Britain's members of parliament, including the governor, have consistently supported the development of new oil palm schemes, especially in the more remote parts of the province. That is partly because they have espoused a conception of 'public-private partnerships' in which the developers of these schemes will fund a major upgrade of

9 Industry sources estimate that the capital cost of an entirely new oil palm scheme in PNG would be close to US\$100 million, and the investment would only make sense if the investor had guaranteed access to 30,000 hectares of land (Ian Orrell, personal communication, February 2011). 
the provincial road network, and partly because oil palm has been seen as suitable substitute for cocoa, formerly the main export crop, which has recently been ravaged by disease (Curry et al. 2011).

The Ili-Wawas Integrated Agriculture Project in the eastern part of Pomio District was the first of this new generation of oil palm schemes in East New Britain, and was heavily promoted by former Member of Parliament Paul Tiensten. It was not investigated by the COI because the SABL that covers the nucleus estate was issued to an ILG rather than a landowner company. Before this lease was issued in November 2008, the developer (Tzen Niugini) had already been logging parts of the project area under 'timber authorities' granted before the Forestry Act was amended in 2007, and continued its logging operations under three FCAs granted in March 2007. These licences covered an area of approximately 50,000 hectares, about half of which was earmarked for the cultivation of oil palm. Tzen Niugini has exported about 500,000 cubic metres of logs from the project area since 2005. The oil palm mill was opened with great ceremony by PNG's Prime Minister and Deputy Prime Minister (the former Provincial Governor) in October 2014. ${ }^{10}$

The Mukus-Melkoi Large Scale Integrated Agriculture Project, on the other hand, is an example of a project that never got off the ground, or to be more precise, has not (so far) gone beyond the paper planning stage. In August 2008, an SABL over 68,300 hectares was issued to a landowner company called Rera Holdings Ltd (RHL) for a period of 99 years. This is the area shown as Portion $2 \mathrm{C}$ in Figure 7.3. Company records show that RHL was incorporated in September 2006, and would count as an 'umbrella company', because its shareholders were three other landowner companies. ${ }^{11}$ As soon as it had been incorporated, the directors had written a letter of invitation to the general manager of a company called Double Dynasty (or DD) Lumber Ltd (DDLL), and Paul Tiensten had written to East New Britain's Provincial Administrator to express his own support for the project (DDLL 2010; Jerewai 2012). DDLL is a subsidiary of Brilliant Investment Ltd, which was able to secure an SABL (in 2007) and an FCA (in 2009) for the Angoram (Marienberg) Integrated Agriculture Project in East Sepik Province (see Table 7.3), and then proceeded to harvest and export about 340,000 cubic metres of logs from that area between 2010

10 Paul Tiensten could not attend the ceremony because he had been convicted of corruption and sent to prison.

11 The three shareholding companies were deregistered in 2009. 
and 2013. However, that project did not include any serious plan for the development of an oil palm estate, and DDLL has not even got as far as logging the Mukus-Melkoi project area. It did manage to secure an FCA over the project area in October 2010, on the basis of a proposal to plant 30,000 hectares of oil palm, but the forester who prepared this proposal told the COI that he had no agricultural qualifications and had not even visited the project area (Jerewai 2012: 134, 141). In February 2011, the managing director of the PNGFA advised the company that its forest clearance plans had not been approved (Numapo 2011:7), and there is no evidence to indicate that new plans have since been submitted.

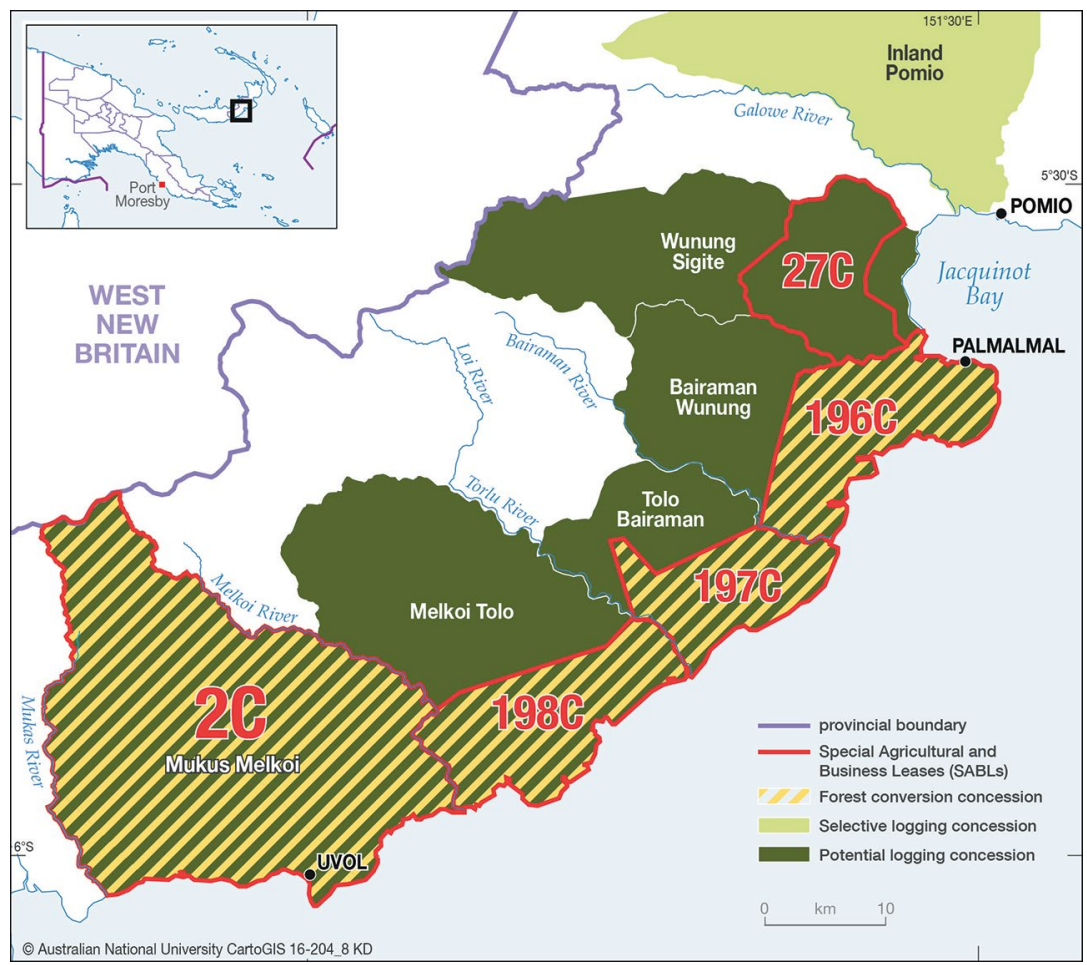

Figure 7.3 Location of SABLs and potential logging concessions in part of Pomio District, East New Britain Province.

Source: CartoGIS, The Australian National University.

The Sigite-Mukus Integrated Rural Development Project is a far more serious venture-more like the Ili-Wawas project. In July 2008, three 99-year SABLs over a combined total of 42,400 hectares of land were simultaneously issued to three landowner companies: Pomata Investment 
Ltd (15,000 hectares), Ralopal Investment Ltd (11,300 hectares), and Nakiura Investment Ltd (16,100 hectares). These are the areas shown in Figure 7.3 as Portions 196C, 197C and 198C. In December 2009, a fourth 99-year SABL over 13,000 hectares of land was issued to another landowner company called Unung Sigite Ltd. This is the area shown as Portion $27 \mathrm{C}$. These four landowner companies, along with two other landowner companies called Ura-Mosi Ltd and Mosi-Ngelu Ltd, are shareholders in an umbrella company called Memalo Holdings Ltd (another MHL), which was incorporated in 2004.

Immediately before this company was incorporated, its directors signed a project agreement with Paul Tiensten and a company called Sumas Timber \& Development International Ltd (STDIL), in which STDIL agreed to lend K300,000 to MHL and Paul Tiensten so that they could secure the cooperation of the local landowners and later arrange for the loan to be repaid from logging revenues. This agreement was attached to an environmental inception report that MHL and STDIL submitted to the Department of Environment and Conservation in July 2006 (MHL and STDIL 2006). This report indicated that the bulk of the local revenues secured from the logging operation would then be used to fund the construction of a road from the Sigite Gorge to the Melkoi River, as well as a nucleus oil palm estate and an associated corridor of smallholder oil palm blocks between 5 and 10 kilometres inland of the shoreline. The proposed road would have the effect of connecting most of the coastal villages in this coastal corridor with the Pomio district headquarters at Palmalmal, on the shores of Jacquinot Bay, and also with the headquarters of the Melkoi local-level government area at Uvol (Figure 7.3).

By April 2008, MHL had abandoned its former deal with STDIL and had signed a new development agreement with Rimbunan Hijau. At the ceremony held to commemorate this event, a senior official from the Lands Department told the assembled landowner company directors that the lease-leaseback arrangement 'would enable the landowners to have more control over their land, unlike before', while the chairman of MHL, John Parulria, reportedly 'urged the civil society to work hand in hand with the lands, forestry and public services sectors to get the projects going' (Anon. 2008). In October that year, one of RH's subsidiary companies, Gilford Ltd, submitted its own development plan to the relevant government authorities (GL and MHL 2008). This document contains copies of sublease agreements covering Portions 196C, 197C and 198C, over which the SABLs had been granted in July that year. 
The East New Britain Provincial Forest Management Committee recommended the grant of an FCA over these three blocks of land in September 2010, and the National Forest Board implemented the recommendation one month later. Shortly afterwards, the vice chairman of MHL, Joe Tali, was reported as saying that 'people were not consulted during the time of the sublease agreement on the selection criteria of the project developer, especially on oil palm', and that 'some nongovernmental organisations and stakeholders had caused confusion and in-fighting among landowner companies on the fair distribution of benefits' (Vuvu 2010). This was an allusion to the fact that members of the 'anti-dependency group' were already helping community groups in two of the four SABL areas to mount a legal challenge to the leasing arrangements (Peter Dam, personal communication, February 2011).

Conflict among the landowners became a national issue in April 2011, after Gilford was reported to have moved its logging equipment into the area, and dissident landowners complained of police harassment when they tried to organise a protest (Anon. 2011a). This prompted Paul Tiensten to announce that he would 'not allow any foreign elements to sabotage my projects', while the Provincial Governor, Leo Dion, 'called on all development partners in East New Britain to stand united for the progressive development of the province' (Nicholas 2011). It is not clear whether news of this particular conflict had any direct influence on the national government's decision to establish the COI, but Greenpeace made sure that the story made much bigger headlines when Commissioner Jerewai arrived in the province to conduct his hearings in November that year (see Chapter 6, this volume).

Greenpeace was not the only 'foreign element' that had an interest in opposing the Sigite-Mukus project. In 1995, around the same time that Collingwood Bay became a place of special interest to conservationists, the European Union began to fund the Islands Region Environment and Community Development Programme in West New Britain Province. This was designed to support small-scale community-based 'eco-forestry projects' as alternatives to large-scale selective logging projects (Bird et al. 2007). This program soon extended its reach to East New Britain, and three such projects were established in the three local government wards located along the coastal margin of what is now Portion 197CBairaman, Lau and Mauna (Scheyvens 2009). These three projects were still being supported by an NGO called the Forest Management and Product Certification Service (commonly known as ForCert), which 
is closely related to PNG's Eco-Forestry Forum, which is the body that nominates an NGO representative to the National Forest Board. PNG's eco-forestry projects have been subsidised by a number of foreign organisations (including Greenpeace) over the past two decades.

It is not surprising that the three coastal wards with eco-forestry projects turned out to be home to some of the landowners most strongly opposed to the agro-forestry project, since the clearance of their native forest would destroy their business model (Paniu 2011). Yet these were only three out of a total of 34 wards in the West Pomio/Mamusi local-level government (LLG) area, which is bounded by the Wunung River in the north and the Melkoi River in the south (Figure 7.3). There were other dissidents to be found in the coastal villages located in Portion 196C, but the dissidents were still greatly outnumbered by supporters of the agro-forestry project who lived beyond the zone covered by the FCA. The political geography of the project area was further complicated by a cultural division between speakers of the Mengen language, who occupy these coastal villages and others around the shores of Jacquinot Bay, and speakers of the Mamusi language, who occupy the coastal villages located in Portion 198C and nearly all of the hinterland villages as well. ${ }^{12}$ The available evidence suggests that the hinterland people have generally supported the agroforestry project, not only because it promised to provide them with better road access to the outside world, but also because it would not destroy their existing land-based livelihoods (Pangkatana 2011; Tiden 2011). The same could even be said of John Parulrea, the chairman of their umbrella company, whose own (Mengen-speaking) village is located at the northern tip of Portion 196C. Aside from his role as chairman of MHL, he is also the chairman of Unung Sigite Ltd, the holder of the SABL over Portion 27C, which is located in the Central/Inland Pomio LLG area. Whether or not the forest in this block of land is eventually cleared for oil palm cultivation, it does not include the adjacent coastal zone from which local villagers derive most of their subsistence (Figure 7.3).

The 2008 development plan (GL and MHL 2008) included a map showing the division of a much larger area, extending inland to the border with West New Britain Province, between six 'consolidated land blocks'. These were the six blocks supposedly represented by the six landowner companies covered by John Parulrea's umbrella company. This

12 There are two wards in the far north of the LLG area, close to the provincial boundary, where another language (Wasi) is spoken. 
map represents a peculiar reconfiguration of this part of Pomio District, which had the effect of eliding the political boundary between two LLG areas at the same time that it distorted the biophysical boundaries between potential logging concessions that had been inscribed in the National Forest Plan. ${ }^{13}$ It is not clear who was responsible for this act of 're-territorialisation', but it seems to have ensured that the coastal Mengenspeaking villagers would be a minority of the landowners represented by 'their' three landowner companies.

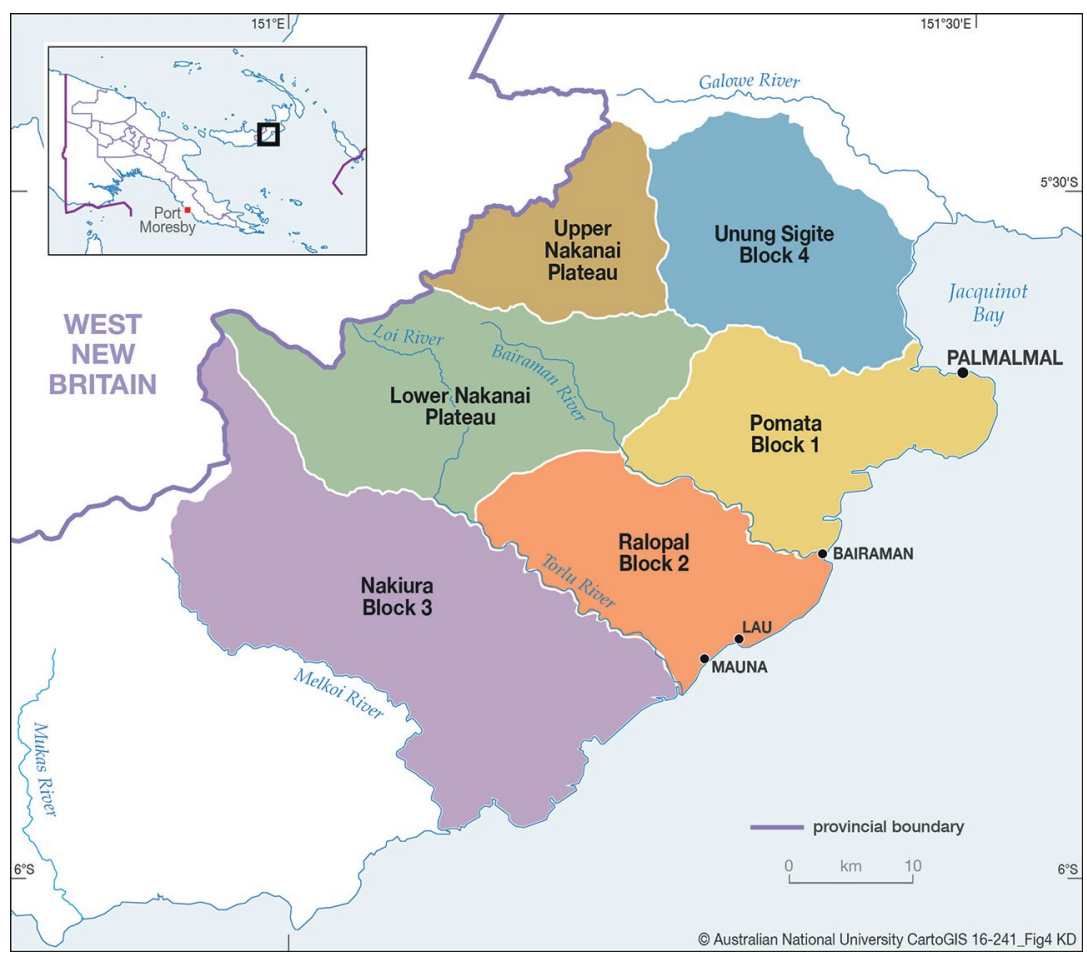

Figure 7.4 Division of the Sigite-Mukus project area into six blocks, with the location of Bairaman, Lau and Mauna council wards in Block 2.

Source: CartoGIS, The Australian National University.

Commissioner Jerewai took no interest in these spatial fault lines. He noted that he could not find any sign of opposition to the project when he visited the area at the end of October 2011, but was interested to discover that the first three witnesses to testify at the first day of hearings

13 In 1995, the National Forest Service had recognised the Upper and Lower Nakanai Plateau areas as potential logging concessions, but not with the same boundaries as those shown in Figure 7.4. 
in Kokopo were all opposed to it (Jerewai 2011a). He then spent two days trying to persuade the landowner company chairmen that their sublease agreements with Gilford were thoroughly unfair and unreasonable (Jerewai 2011b, 2011c). At one point, he chided the chairman of Nakiura Investment Ltd:

It is like you have been placed in a boxing ring, pushed into one corner and you cannot get out of it. The only way is to go down-it is a knockout (Jerewai 2011b: 102).

Jerewai's other main concern was to figure out why men had occupied all the positions of authority from which the leasing arrangements had been negotiated, when the local custom of matrilineal inheritance surely meant that women were the true landowners (Jerewai 2011d, 2011e). One of the male witnesses explained this apparent paradox as follows:
Yes, it is true that the women are- through women, land is passed on. But in the Pomio custom, man is in charge of partaking in discussions about land matters, dealing with land boundaries, and dealing with disputes within the clan or among clans, and dealing with the houseboy where important issues about the lives of Pomio people are discussed by men ... (Jerewai 2011e: 5).

In May 2012, Greenpeace produced a press release declaring that the Supreme Court had upheld an appeal by MHL against previous court decisions that would have allowed for judicial review of the leasing arrangements for the Sigite-Mukus project (Greenpeace 2012). We have not been able to discover the trail of court proceedings, which had apparently begun when Gilford landed its logging equipment in April 2011, and there is some confusion about which court made what orders at what point in time. In any case, the dissident landowners and their allies now switched the main focus of their campaign from the problem of consent, as investigated by the COI, to the problem of violence, as manifested in a sequence of police raids that also began when the logging equipment was first landed in the area (Anon. 2011a; Makis 2011; Tiden 2012a, 2012b). In October 2012, a 'fact-finding mission' arrived in the area to investigate previous allegations of police brutality against the residents of five villages-including Bairaman, Lau and Mauna-in light of an announcement previously made by the police commissioner that he had ordered 'the withdrawal of all police personnel from logging camps following allegation of abuse of power against them' (Anon. 2011b). 
This expedition seems to have been organised by the Eco-Forestry Forum, but supposedly included representatives from a number of government agencies, including the police force itself. The resulting report documented several instances of police brutality, some of which had not been reported in the national newspapers, and concluded that the officers responsible had been 'used by Gilford Ltd for their purposes which is to thwart any attempt by the local people to stop the logging operation' (IFFM 2013: 19). However, it also attached a letter in which the police sergeant who accompanied the team acknowledged that the police were accommodated at the logging camp, but 'were there on the request of the landowner company through its chairman to deal with the law and order issues which is [sic] on the rise since the company moved into the area' (ibid.: 24). His argument echoed the line consistently taken in the pages of The National newspaper, which happens to be owned by $\mathrm{RH}$, in response to stories published by its opposite number, the PostCourier (Anon. 2011c, 2011d, 2011e, 2012b). As if to anticipate the findings of the 'fact-finding mission', The National also published an article reporting that 10 government officials had conducted their own fact-finding mission in September 2012, from which they had concluded that there was no truth to claims being made by opponents of the project that local people had been 'affected by an increase of sexual transmitted diseases, prostitution, pornography, domestic violence in the logging camps and nurseries, gambling, stealing of garden food, academic level of schools declining in the project area, underage employment and chemical contamination' (Apina 2012).

The next round in the contest took place towards the end of 2013, after the publication of the two final reports of the COI, when the dissidents reportedly sent a petition to the Prime Minister demanding the revocation of the SABLs granted over Portions 196C, 197C and 198C (Kolma 2013). When this had no effect, the dissidents took another tack. In August 2014, Bairaman, Lau and Mauna ward councillors, along with the representatives of 15 local land groups, wrote to the chairman of the National Forest Board, requesting that Gilford's FCA should not be renewed when it expired in October 2014. The key point in their argument was that these land groups had been incorporated in 2003, when the eco-forestry projects were initiated, but a different set of land groups had been fraudulently incorporated in 2006 as part of the political process that led to the grant of the SABL over Portion 197C (Samo et al. 2014). 


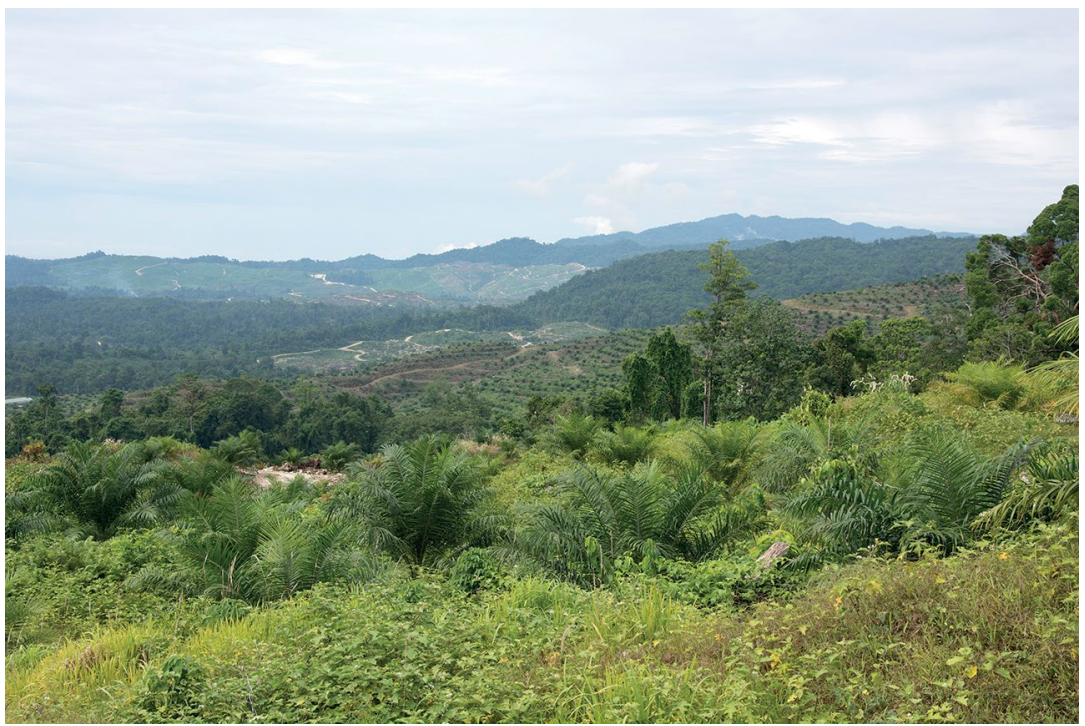

Figure 7.5 Forest cleared for cultivation of oil palm in Portion 196C, February 2015.

Source: Photograph by Simon Foale.

Their request was backed by several local NGOs, and also by the Londonbased Global Witness, which had come to occupy the space previously occupied by Greenpeace in the land grab policy network (see Chapter 8, this volume). Although the chairman was at that time the board member who had been nominated by the Eco-Forestry Forum, and seems to have sympathised with the request, the National Forest Board accepted the recommendation of East New Britain's Provincial Forest Management Committee and renewed the FCA for a further six years. The dissident landowners then went back to court to obtain another injunction that apparently failed to halt the process of forest clearance (PNGexposed 2014), while Global Witness published a report that showed the extent of the clearance that had already taken place in Portions 196C and 198C (Global Witness 2014). RH responded in the same way that it had previously responded to attacks by members of the anti-dependency group: by hiring the Australian-based consulting firm ITS Global to document the social and economic benefits of the project and refute all claims previously made about its negative social and environmental 
impact (ITS Global 2014). ${ }^{14}$ In 2014, the company managed to export almost 340,000 cubic metres of logs from the project area-100,000 more than it had exported in the previous year.

By the end of 2014, Portion 197C had barely been logged at all, and the court injunction may have served to keep the chainsaws at bay. However, we understand that the injunction was lifted in July 2015, and satellite imagery confirms that forest clearance is now proceeding at a rate equivalent to that seen in the other two portions.

\section{Conclusion}

Palm oil companies have been looking to other countries, including PNG, as land availability in the largest producing countries, Malaysia and Indonesia, has been reduced. However, some of the larger palm oil companies have delayed investment in PNG because of problems with the legitimacy (and legal contestability) of the land titles being offered to them (Ian Orrell, personal communication, February 2013). SABLS have failed to offer security of land tenure, largely because relationships between players are dynamic, with changes in bargaining power being fuelled by a discourse that raises rural people's hopes and expectations, driven by actors who benefit from short-term deals.

Some simple changes in negotiation procedures might have a large impact on landowner equity. For example, lease and sublease agreements should be signed in the district where the land is located, or even within the boundaries of the lease area itself, not in Port Moresby or provincial capitals. That might make landowner companies more accountable to the landowners. The land investigation process should also be improved, as Commissioner Numapo pointed out: 'Landowners must be free to attach qualification or conditions to their consent if they wish because merely offering signatures may not reflect their real (contextual or relative) position' (Numapo 2013: 66). The COI recommended a review of the current lease-leaseback provisions under the Land Act, with a 50-year cap on the lease period. The COI also recommended the promulgation of a regulation that clearly sets out the 'processes and procedures' relating to the SABL application, registration, processing, approval and issuance. This would mean that non-compliance with prescribed procedures and

14 Their report also purported to show that the local eco-forestry projects produced no benefits at all. 
processes (including those related to demonstration of developer capacity) would render the whole SABL null and void (Numapo 2013: 263-4). Transparency in the structure of sublease agreements is also critical to the avoidance of fraud or injustice.

Developers and their relationships with landowners are likely to evolve further in the future. Of the land controlled by companies that have recently acquired an interest in developing plantations, most is under serious legal dispute, which constitutes an obstacle to development, but some of the larger companies could feasibly weather the risks and costs of such problems and eventually develop plantations and mills, perhaps taking over the leases of companies that have failed or have completed logging activities. To manage risks over customary land use for oil palm development, it may be increasingly important for landowners to draw upon the Fairness of Transactions Act, which allows for the reopening and review of any transaction irrespective of fault and validity, enforceability or effect, of any agreement. This law is intended to ensure the fair distribution and adjustment of rights, benefits, duties, advantages and disadvantages arising out of a transaction, but has hardly ever been applied. It is critically important to address the breakdown and subversion of processes intended for genuine and equitable agro-forestry ventures in PNG, because failed or stalled developments mean that landowners and companies both forego substantial sustained income if agricultural developments do not eventuate. Moreover, if poverty alleviation is a key goal of the mobilisation of customary land for palm oil production, it is important to ensure that the process of establishing and negotiating a lease or sublease for development purposes does not accelerate impoverishment.

Communities across Melanesia have sought to pursue their own 'roads to development' (Curry 2003). Our research has shown how land groups and landowner companies sometimes deal with multiple developers as they attempt to shape the political landscape of large-scale resource development. At the same time, dissenting landowner groups are mobilising the support of international NGOs in the hope of restorative justice. As we have highlighted, one of the key strategies adopted in PNG has been the establishment of linkages between landowners and international NGOs to address the social and political dimensions of palm oil production. To address the power imbalances between developers, state actors and customary landowner groups, the strengthening of long-term relationships built on trust, respect and honesty, as well as transparent communication and information, will be critical. In PNG, increased 
interaction with accelerated technological developments has resulted in an upsurge in the use of social media and internet forums by PNG landowners, providing a framework for communication and partnership. Although these socio-technical forms of engagement are currently largely restricted to protesting against social injustice in resource projects, the development of resilient network structures may also help marginalised people to pursue other goals. However, unless the PNG government keeps its promise to support positive reform, the legitimacy and equity of foreign investment in new oil palm schemes remains highly questionable.

\section{References}

Allen, B., 2009. 'Agricultural Development, Policies and Governance.' In R.M. Bourke and T. Harwood (eds), Food and Agriculture in Papua New Guinea. Canberra: ANU E Press.

Amnesty International, 2014. Injustice Incorporated: Corporate Abuses and the Human Right to Remedy. London: Amnesty International.

Anderson, T., 2010. 'Land Registration, Land Markets and Livelihoods in Papua New Guinea.' In T. Anderson and G. Lee (eds), In Defence of Melanesian Customary Land. Sydney: Aid/Watch.

Anderson, T. and G. Lee, 2010. 'Introduction: Understanding Melanesian Customary Land.' In T. Anderson and G. Lee (eds), In Defence of Melanesian Customary Land. Sydney: Aid/Watch.

Anon., 2008. 'Pact Signed to Develop Pomio District.' Post-Courier, 15 April.

—, 2010. 'Land Status Halts Oro Agri Projects.' Post-Courier, 11 November.

__, 2011a. 'Loggers Enter Land Without Notice.' Post-Courier, 8 April.

— , 2011b. 'Top Cop Removes Officers from Logging Camps.' The National, 8 December.

— , 2011c. 'Firm Denies Police Went to Arrest Locals.' The National, 12 April.

_ 2011 d. 'Administrator Denies Brutality.' The National, 13 October. 
__, 2011 e. 'NGOs Told Not to Halt Project.' The National, 13 October.

__, 2012a. 'Malaysian Firm Eyes Oil Palm Plantations.' The National, 5 October.

__, 2012b. 'Police: Pomio Brutality Claims False and Malicious.' The National, 30 April.

Anseeuw, W., M. Boche, T. Breu, M. Giger, J. Lay, P. Messerli and K. Nolte, 2012. 'Transnational Land Deals for Agriculture in the Global South: Analytical Report Based on the Land Matrix Database.' Bern: International Land Coalition.

Apina, A., 2012. 'Pomio Officials Deny Any Social Disorder at Oil Palm Project.' The National, 8 October.

Barker, J., 2004. 'Between Heaven and Earth: Missionaries, Environmentalists and the Maisin.' In V. Lockwood (ed.), Globalization and Culture Change in the Pacific Islands. Upper Saddle River (NJ): Pearson Prentice Hall.

Barker, P., 2009. 'Land Grab-A Sinister Cycle.' Post-Courier, 11 May.

Bird, N., A. Wells, F. van Helden and R. Turia, 2007. 'Issues and Opportunities for the Forest Sector in Papua New Guinea.' London: Overseas Development Institute (Papua New Guinea Forest Studies 3).

Cotula, L., 2013. 'Reshaping Contracts for Quality Natural Resource Investments.' London: International Institute for Environment and Development.

Cotula L., S. Vermeulen, P. Mathieu and C. Toulmin, 2011. 'Agricultural Investment and International Land Deals: Evidence from a MultiCountry Study in Africa.' Food Security 3: S99-S113. doi.org/10.1007/ s12571-010-0096-x.

Cramb, R. and G.N. Curry, 2012. 'Oil Palm and Rural Livelihoods in the Asia-Pacific Region: An Overview.' Asia Pacific Viewpoint 53: 223-239. doi.org/10.1111/j.1467-8373.2012.01495.x.

Curry, G.N., 2003. 'Moving Beyond Postdevelopment: Facilitating Indigenous Alternatives for "Development".' Economic Geography 79: 405-442. doi.org/10.1111/j.1944-8287.2003.tb00221.x. 
Curry, G., J. Lummami and E. Omuru, 2011. 'Socioeconomic Impact Assessment of Cocoa Pod Borer in East New Britain Province, Papua New Guinea.' Canberra: Australian Centre for International Agricultural Research.

DDLL (Double Dynasty Lumber Ltd), 2010. 'Environmental Permit Application to Discharge Waste: Mukas-Melkoi Large Scale Integrated Agriculture Project.' Unpublished report to PNG Department of Environment and Conservation.

Deininger, K. and D. Byerlee, 2011. Rising Global Interest in Farmland: Can It Yield Sustainable and Equitable Benefits? Washington (DC): World Bank. doi.org/10.1596/978-0-8213-8591-3.

Feintrenie, L., 2014. 'Agro-Industrial Plantations in Central Africa: Risks and Opportunities.' Biodiversity and Conservation 23: 1577-1589. doi.org/10.1007/s10531-014-0687-5.

Filer, C., 2011. 'New Land Grab in Papua New Guinea.' Pacific Studies 34: 269-294.

_-, 2012a. 'Why Green Grabs Don't Work in Papua New Guinea.' Journal of Peasant Studies 39: 599-617. doi.org/10.1080/03066150. 2012.665891.

_ 2012b. 'The Commission of Inquiry into Special Agricultural and Business Leases in Papua New Guinea: Fresh Details for the Portrait of a Process of Expropriation.' Paper presented at second international workshop on 'Global Land Grabbing', Cornell University, 17-19 October.

_ 2013. 'Asian Investment in the Rural Industries of Papua New Guinea: What's New and What's Not?' Pacific Affairs 86: 305-326. doi.org/10.5509/2013862305.

Filer, C. with N. Sekhran, 1998. Loggers, Donors and Resource Owners. London: International Institute for Environment and Development in association with the National Research Institute (Policy That Works for Forests and People, Papua New Guinea Country Study).

Gangai, A., 2010. 'Collingwood Bay Community Consensus: We Will Be the Masters of Our Own Destiny.' Popondetta: Oro Community Environmental Action Network. 
GL (Gilford Ltd) and MHL (Memalo Holdings Ltd), 2008. 'ADevelopment Plan for the Establishment of Oil Palm and Forest Plantations in the Sigite-Mukus Consolidated Land Area.' Unpublished report to PNG Department of Agriculture and Livestock.

Global Witness, 2014. 'The People and Forests of Papua New Guinea under Threat: The Government's Failed Response to the Largest Land Grab in Modern History.' London: Global Witness.

GoPNG (Government of PNG), 2007. National Agriculture Development Plan 2007-2016 (2 volumes). Port Moresby: Ministry of Agriculture and Livestock.

Greenpeace, 2012. 'Landowners Committed to Fighting Pomio SABLs Despite Court Ruling.' Media release, 2 May.

IFFM (Independent Fact Finding Mission), 2013. 'Investigation of Police Brutality-West Pomio, ENBP.' Viewed 18 October 2016 at: pngexposed.files.wordpress.com/2014/11/investigation-of-policebrutality-west-pomio.pdf.

ITS Global, November 2014. 'Bearing False Witness: A Critique of Global Witness' Anti-Development Activity in East New Britain.' Unpublished report to Rimbunan Hijau (PNG) Ltd.

Jerewai, A., 2011a. Transcript of SABL Commission of Inquiry hearing, Kokopo, 2 November.

—_, 2011b. Transcript of SABL Commission of Inquiry hearing, Kokopo, 3 November.

—_, 2011c. Transcript of SABL Commission of Inquiry hearing, Kokopo, 4 November.

—_, 2011d. Transcript of SABL Commission of Inquiry hearing, Kokopo, 9 November.

__, 2011e. Transcript of SABL Commission of Inquiry hearing, Kokopo, 11 November.

—_, 2012. Transcript of SABL Commission of Inquiry hearing, Kimbe, 10 February. 
KLK (Kuala Lumpur Kepong Bhd), 2013a. Annual Report 2013. Kuala Lumpur: KLK.

— 2013b. 'Replies to Complaints Made by the Oro Community Environmental Action Network ("OCEAN") and Collingwood Bay Conservation and Development Association ("CCADA") in Respect of KLK's Operations in Papua New Guinea (“PNG”).' Letter to RSPO Secretariat, 10 December.

_ 2016. 'KLK Commits to Address Grievances Raised by Rainforest Action Network (“RAN”).' Viewed 18 October 2016 at: www.klk. com.my/wp-content/uploads/2016/03/ResponsetoRAN.pdf.

Koczberski, G., G.N. Curry, D. Rogers, E. Germis and M. Koi, 2013. 'Developing Land-Use Agreements in Commodity Cash Crop Production that Meet the Needs of Landowners and Smallholders.' In G. Hickey (ed.), Socioeconomic Agricultural Research in Papua New Guinea. Canberra: Australian Council for International Agricultural Research (Proceedings 141).

Kolma, F., 2013. 'West Pomio Landowners Fed Up.' Post-Courier, 20 December.

Lattas, A., 2014. 'Logging in Pomio: Violence, Wages, Land and the Environment.' PNGexposed blogpost, 22 September. Viewed 18 October 2016 at: pngexposed.wordpress.com/2014/09/22/logging -in-pomio-violence-wages-land-and-the-environment/.

Makis, M., 2011. 'Pomio DA Refutes Reports of Police Brutality.' Post-Courier, 13 October.

MCL (Musa Century Ltd), 2008. 'Environmental Impact Statement for Musa-Pongani Agro-Forestry Project, Safia District, Oro Province.' Unpublished report to PNG Department of Environment and Conservation.

MHL (Memalo Holdings Ltd) and STDIL (SumasTimber \& Development International Ltd), 2006. 'An Environment Inception Report for Sigite-Mukus Rural Integrated Development Project.' Unpublished report to PNG Department of Environment and Conservation. 
Mirou, N., 2013. Commission of Inquiry into Special Agriculture and Business Lease (C.O.I. SABL): Report. Port Moresby: Government of Papua New Guinea. Viewed 5 October 2016 at: www.coi.gov.pg/ documents/COI\%20SABL/Mirou\%20SABL\%20Final\%20Report.pdf.

Moore, E., 2011. 'The Administration of Special Purpose Agricultural and Business Leases: Customary Land and the Lease-Lease-Back System.' Port Moresby: National Research Institute (Discussion Paper 118).

Mousseau, F., 2013. 'On Our Land: Modern Land Grabs Reversing Independence in Papua New Guinea.' Oakland (CA): The Oakland Institute in collaboration with Pacific Network on Globalisation.

Nayak, P.K., L.E. Oliveira, and F. Berkes, 2014. 'Resource Degradation, Marginalization, and Poverty in Small-Scale Fisheries: Threats to Social-Ecological Resilience in India and Brazil.' Ecology and Society 19(2): 73. doi.org/10.5751/ES-06656-190273.

Nelson, P.N., J. Gabriel, C. Filer, M. Banabas, J.A. Sayer, G.N. Curry, G. Koczberski and O. Venter, 2014. 'Oil Palm and Deforestation in Papua New Guinea.' Conservation Letters 7: 188-195. doi. org/10.1111/conl.12058.

Nelson, P.N., M.J. Webb, I. Orrell, H. van Rees, M. Banabas, S. Berthelsen, M. Sheaves, F. Bakani, O. Pukam, M. Hoare, W. Griffiths, G. King, P. Carberry, R. Pipai, A. McNeill, P. Meekers, S. Lord, J. Butler, T. Pattison, J. Armour and C. Dewhurst, 2010. Environmental Sustainability of Oil Palm Cultivation in Papua New Guinea. Canberra: Australian Centre for International Agricultural Research (Technical Report 75).

Nicholas, I., 2011. 'Tiensten Warns NGOs with Motives to Stay Out.' The National, 19 April.

Nilles, J., 2010. 'Report: Wanigela.' Port Moresby: Centre for Environmental Law and Community Rights.

Nolte, K., 2014. 'Large-Scale Agricultural Investments under Poor Land Governance in Zambia.' Land Use Policy 38: 698-706. doi. org/10.1016/j.landusepol.2014.01.014.

Numapo, J., 2011. Transcript of SABL Commission of Inquiry hearing, Waigani, 4 October. 
— 2012. Transcript of SABL Commission of Inquiry hearing, Popondetta, 16 February.

—, 2013. Commission of Inquiry into the Special Agriculture and Business Lease (SABL): Final Report. Port Moresby: Government of Papua New Guinea. Viewed 5 October 2016 at: www.coi.gov.pg/documents/ COI\%20SABL/Numapo\%20SABL\%20Final\%20Report.pdf.

Numapo, J., A. Jerewai and N. Mirou, 2011. Transcript of SABL Commission of Inquiry hearing, Waigani, 8 September.

OCEAN (Oro Community Environmental Action Network) and CBCDA (Collingwood Bay Conservation and Development Association), 2013. 'Complaint against Kuala Lumpur Kepong.' Submission to RSPO Secretariat, 19 April.

Oliver, N., 2002. 'Lease, Lease-Back: An Instrument for Forestry?' In C. Hunt (ed.), Production, Privatisation and Preservation in Papua New Guinea Forestry. London: International Institute for Environment and Development.

Pangkatana, J., 2010. 'Illegal Loggers Nailed!' Post-Courier, 18 August.

—_, 2011. 'Stop the Land Grab.' Post-Courier, 29 October.

Paniu, L., 2011. 'LOs Stage Peaceful Protest.' Post-Courier, 10 August.

PNGexposed, 2014. 'Rimbunan Hijau Ignoring Court Order to Stop Logging Operations.' Anonymous blogpost, 24 November. Viewed 18 October 2016 at: pngexposed.wordpress.com/2014/11/24/ rimbunan-hijau-ignoring-court-order-to-stop-logging-operations/.

Pok, J., 2010. 'State to Give Land Back to Landowners.' The National, 3 February.

—_, 2012. 'Oro SABL's Queries.' Post-Courier, 14 September.

Power, T., 2008. 'Incorporated Land Groups in Papua New Guinea.' In AusAID (Australian Agency for International Development) (ed.), Making Land Work_-Volume Two: Case Studies on Customary Land and Development in the Pacific. Canberra: AusAID. 
RAN (Rainforest Action Network), 2014. 'Contested KLK Palm Oil Leases Declared Illegal by Papua New Guinea Court.' Press release, 21 May. Viewed 18 October 2016 at: www.ran.org/contested-klkpalm-oil-leases-declared-illegal-papua-new-guinea-court.

Rulli, M.C., and P. D'Odorico, 2014. 'Food Appropriation through Large Scale Land Acquisitions.' Environmental Research Letters 9: 064030. doi.org/10.1088/1748-9326/9/6/064030.

Rulli M.C., A. Saviori and P. D'Odorico, 2013. 'Global Land and Water Grabbing.' Proceedings of the National Academy of Sciences 110: 892-897. doi.org/10.1073/pnas.1213163110.

Samo, J., D. Mane, P. Kene, and 15 others, 2014. Letter to Thomas Paka, Chairman of the National Forest Board, 20 August.

Sayer, J., J. Ghazoul, P. Nelson and A.K Boedhihartono, 2012. 'Oil Palm Expansion Transforms Tropical Landscapes and Livelihoods.' Global Food Security 1: 114-119. doi.org/10.1016/j.gfs.2012.10.003.

Scheyvens, H., 2009. 'Forest Management and Product Certification Service (PNG): Socio-Economic Impact Survey.' Kanagawa: Institute for Global Environmental Strategies.

SGS PNG Ltd, 2008-2015. 'Log Export Statistics and Export Monitoring Highlights-Table 11: Monthly Actual Shipped Volumes (m3) by Export Company and Project.' Port Moresby: SGS PNG Ltd.

Sheil, D., A. Casson, E. Meijaard, M. van Noordwijk, J. Gaskell, J. Sunderland-Groves, K. Wertz and M. Kanninen, 2009. 'The Impacts and Opportunities of Oil Palm in Southeast Asia: What Do We Know and What Do We Need to Know?' Bogor: Center for International Forestry Research (Occasional Paper 51).

SML (Sibo Management Ltd), 2014. 'Press Release: Collingwood Bay Chiefs of Legigtimate [sic] Clans Speak Out.' Post-Courier, 3 January.

Sutherlin, L., 2013. 'Papua New Guinea Tribes under Threat from Conflict Palm Oil.' Act Now blogpost, 13 November. Viewed 18 October 2016 at: www.actnowpng.org/content/papua-new-guineatribes-under-threat-conflict-palm-oil.

Tiden, G., 2011. 'Log Ops Stop Bid Opposed.' Post-Courier, 19 April. 
__ 2012a. 'Police Force Pomio Villagers to Sign Logging Documents.' Post-Courier, 7 March.

—_, 2012b. '10 Held for Blocking Stream.' Post-Courier, 12 April.

Toft K.H., 2013. 'Are Land Deals Unethical? The Ethics of Large-Scale Land Acquisitions in Developing Countries.' Journal of Agricultural and Environmental Ethics 26: 1181-1198. doi.org/10.1007/s10806013-9451-1.

Von Braun J. and R. Meinzen-Dick, 2009. 'Land Grabbing by Foreign Investors in Developing Countries: Risks and Opportunities.' Washington (DC): International Food Policy Research Institute (Policy Brief 13).

Vuvu, E., 2010. 'Oil Palm Growers Warned of Impacts.' The National, 23 November.

Winn, P., 2012. 'Up for Grabs: Millions of Hectares of Customary Land in PNG Stolen for Logging.' Sydney: Greenpeace Australia Pacific. 
This text is taken from Kastom, property and ideology: Land transformations in Melanesia, edited by Siobhan McDonnell, Matthew Allen and Colin Filer, published 2017 by ANU Press, The Australian National University, Canberra, Australia. 